MARCOS GOMES LOPES

\title{
Infecção por Rickettsia spp em equídeos e carrapatos do Centro-Norte do Piauí
}





\section{Infecção por Rickettsia spp em equídeos e carrapatos do Centro-Norte do Piauí}

Dissertação apresentada ao Programa de Pós-Graduação em Epidemiologia Experimental Aplicada às Zoonoses da Faculdade de Medicina Veterinária e Zootecnia da Universidade de São Paulo para obtenção do título de Mestre em Ciências

Departamento:

Medicina Veterinária Preventiva e Saúde Animal

Área de concentração:

Epidemiologia Experimental Aplicada às Zoonoses

Orientador:

Prof. ${ }^{a}$ Dra ${ }^{\underline{a}}$. Solange Maria Gennari

São Paulo 
Autorizo a reprodução parcial ou total desta obra, para fins acadêmicos, desde que citada a fonte.

\section{DADOS INTERNACIONAIS DE CATALOGAÇÃO-NA-PUBLICAÇÃO}

(Biblioteca Virginie Buff D’Ápice da Faculdade de Medicina Veterinária e Zootecnia da Universidade de São Paulo)

T.2597

FMVZ

\section{Lopes, Marcos Gomes}

Infecção por Rickettsia spp em equídeos e carrapatos do Centro-Norte do Piauí / Marcos Gomes Lopes. -- 2012.

84 p. : il.

Dissertação (Mestrado) - Universidade de São Paulo. Faculdade de Medicina Veterinária e Zootecnia. Departamento de Medicina Veterinária Preventiva e Saúde Animal, São Paulo, 2012.

Programa de Pós-Graduação: Epidemiologia Experimental e Aplicada às Zoonoses.

Área de concentração: Epidemiologia Experimental e Aplicada às Zoonoses.

Orientador: Profa. Dra. Solange Maria Gennari.

1. Asininos. 2. Equinos. 3. Piauí. 4. Rickettsia. I. Título. 


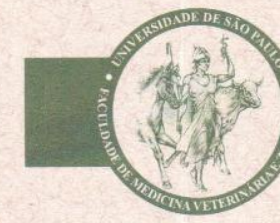

UNIVERSIDADE DE SĀO PAULO

FACULDADE DE MEDICINA VETERINÁRIA E ZOOTECNIA

\section{Comissão de Ética no uso de animais}

\section{CERTIFICADO}

Certificamos que o Projeto intitulado "Evidências sorológicas e moleculares da infecção por Rickettsia spp. em carrapatos e equídeos do centro norte do Piauí", protocolado sob o $\mathrm{n}^{\circ}$ 2396/2011, utilizando 150 (cento e cinquenta) jegues e cavalos, sob a responsabilidade do (a) Profa. Dra. Solange Maria Gennari, está de acordo com os princípios éticos de experimentação animal da "Comissão de Ética no uso de animais" da Faculdade de Medicina Veterinária e Zootecnia da Universidade de São Paulo e foi aprovado em reunião de 17/8/2011.

We certify that the Research "Serological and molecular evidences of Rickettsia spp. infection in ticks and equines in center-north of Piauí", protocol number 2396/2011, utilizing 150 (one hundred and fifty) donkeys and horses, under the responsibility Profa. Dra. Solange Maria Gennari, agree with Ethical Principles in Animal Research adopted by "Ethic Committee in the use of animals" of the School of Veterinary Medicine and Animal Science of University of São Paulo and was approved in the meeting of day $8 / 17 / 2011$.

São Paulo, 7 de outubro de 2011.

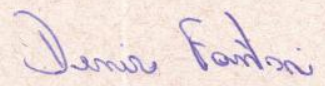

Denise Tabacchi Fantoni

Presidente 



\section{FOLHA DE AVALIAÇÃO}

Nome: LOPES, Marcos Gomes

Título: Infecção por Rickettsia ssp em equídeos e carrapatos do CentroNorte do Piauí

Dissertação apresentada ao Programa de Pós-Graduação em Epidemiologia Experimental Aplicada às Zoonoses da Faculdade de Medicina Veterinária e Zootecnia da Universidade de São Paulo para obtenção do título de Mestre em Ciências

Data:

\section{Banca Examinadora}

Prof.Dr

Instituição: Julgamento:

Prof. Dr. Instituição: Julgamento:

Prof. Dr. Instituição: Julgamento: 



\section{DEDICATÓRIA}

Dedico a querida Profa Dra Ivete Lopes de Mendonça que me pariu para a ciência. 



\section{AGRADECIMENTOS}

Se fui parido para ciência, tive a sorte de ser adotado por uma mãe que me ensinou alçar voo! Hoje sonho em conseguir voar ao seu lado e aprender mais sobre como ver as coisas de cima. Obrigado Prof $^{\mathrm{a}} \mathrm{Dr}^{\mathrm{a}}$ Solange Maria Gennari!

Ao Prof ${ }^{\circ}$ Dro Marcelo Bahia Labruna, pela oportunidade de estudar sob a luz de seu conhecimento, me sinto honrado.

A minha Família pelo auxilio material, espiritual e psicológico.

Aos meus pais Manoel Lopes de Sousa e Vitoria Cedomia R. Gomes, amor é tudo!

Ao amigo Kleber Portela Fortes que esteve comigo desde o inicio do projeto, realizar as coletas com você não foi trabalho. Obrigado!

Ao amigo Jonas Morais que nunca me deixou sem laminas de RIFI ou sem um sorriso. Vai Corinthians!

Ao amigo Thiago pela paciência e ensinamentos sobre carrapatos e organização! "È nois mano"!

Aos amigos Fernanda Neri e Arlei Neri pela orientação sempre que necessitei. Obrigado!

Aos amigos Amália Regina, Danilo Saraiva e Herbert Soares, que além de dividir seus dias e noites comigo, também me deram de seus conhecimentos sempre que precisei. Obrigado! 
Ao amigo Bruno Bertassoli por toda sua gentileza e pelo excelente trabalho na edição desta dissertação, muito obrigado!

Aos amigos Francisco e Andréia pelas ajudas e conselhos em todo o decorrer do trabalho. Obrigado!

A amiga Gisele Aires que não mediu esforços para me ensinar não só sobre ciências mas também sobre a vida, obrigado!

A amiga Aline que realizou toda a estatística, sempre atenciosa, disponível e profissional. Muito obrigado!

Ao amigo Danival que sempre, direta ou indiretamente, nos auxilia tornando bem mais fácil e agradável nosso caminho! Obrigado!

A todos que fazem e fizeram parte da grande família VPS.

A Deus, por todas essas pessoas na minha vida! 
Atirei no que vi, acertei o que não vi e fui Feliz! 



\section{RESUMO}

LOPES, M. G. Infecção por Rickettsia ssp em equídeos e carrapatos do CentroNorte do Piauí. [Infection with Rickettsia spp in horses and donkeys and ticks in the Center-North of Piaui]. 2012. 84 f. Dissertação (Mestrado em Ciência) - Faculdade de Medicina Veterinária e Zootecnia, Universidade de São Paulo, São Paulo, 2012.

Com o objetivo de avaliar sorológica e molecularmente a ocorrência de infecção por Rickettsia spp em equídeos e carrapatos da região Centro-Norte do estado do Piauí, foram realizadas coletas de sangue e de carrapatos que parasitavam equídeos em 10 localidades distribuídas nas microrregiões de: Campo Maior, Teresina e Valença, nos meses de agosto dos anos de 2010 e 2011. Soros de 129 equinos e 110 asininos foram analisados pela Reação de Imunofluorescência Indireta para detecção de anticorpos anti-Rickettsia spp ( $R$. rickettsii, $R$. parkeri, $R$. amblyommii, R. rhipicephali e R. bellii) e 105 Dermacentor nitens, oito Amblyomma cajennense e três Amblyomma parvum foram submetidos a reação de polimerase em cadeia utilizando os primers dos genes gltA, ompA e ompB específicos para o gênero Rickettsia e rickettsias do grupo da febre maculosa (GFM). Do total de animais examinados $52,3 \%$ foram positivos para pelo menos uma das rickettsias testadas. Somente em dois carrapatos dos 116 analisados, ambos $A$. parvum, foram positivos para Rickettsia do GFM, apresentando esta cepa 100\% de similaridade com "Candidatus Rickettsia andeanae", obtida no Peru. Pelos achados sorológicos concluiu-se que "Candidatus Rickettsia andeanae" cepa Piauí e ou R. amblyommii, seriam juntamente com $R$. bellii, os prováveis agentes circulantes na região centronorte do estado do Piauí. $D$. nitens, $A$. cajennense e $A$. parvum são espécies de carrapatos que infestam equídeos na mesorregião Centro-Norte do Piauí. "Candidatus Rickettsia andeanae" cepa Piauí teve seu primeiro relato no Brasil. Animais com acesso à mata ou mantidos em piquetes apresentaram associação com a ocorrência de anticorpos anti-Rickettsia spp $(p<0.01)$.

Palavras-chave: Asininos, Equinos, Piauí, Rickettsia 



\section{ABSTRACT}

LOPES, M. G. Infection with Rickettsia spp in horses and donkeys and ticks in the Center-North of Piaui. [Infecção por Rickettsia ssp em equídeos e carrapatos do Centro-Norte do Piauí]. 2012. 84 f. Dissertação (Mestrado em Ciência) Faculdade de Medicina Veterinária e Zootecnia, Universidade de São Paulo, São Paulo, 2012.

In order to evaluate serological and molecular occurrence of infection with Rickettsia spp in horses and ticks in the central-northern region of the state of Piauí, blood samples were taken and ticks infesting horses are collected in ten locations distributed in the regions of: Campo Maior, Teresina and Valença, in August of 2010 and 2011. Sera from 129 horses and 110 donkeys were analyzed by immunofluorescent antibody test for detection of antibodies to Rickettsia spp ( $R$. rickettsii, $R$. parkeri, $R$. amblyommii, $R$. rhipicephali and $R$. bellii) and 105 Dermacentor nitens, eight Amblyomma cajennense and three Amblyomma parvum were subjected to PCR analysis using primers of the genes gltA, ompA and ompB specific to the genus Rickettsia and spotted fever group (SFG). From all of the examined animals, $52.3 \%$ were positive for at least one of Rickettsia tested. Only two of the 116 ticks analyzed, both A. parvum, were positive for Rickettsia of the SFG, and the strain showing 100\% similarity with 'Candidatus Rickettsia andeanae" obtained in Peru. By the serological finds it was concluded that "Candidatus Rickettsia andeanae" strain Piauí and or R. amblyommii, together with $R$. bellii, are probably the agents circulating in the central-northern region of Piauí state. D. nitens, $A$. cajennense and $A$. parvum are species of ticks that infest horses in the region. "Candidatus Rickettsia andeanae" strain Piauí was firstly described in ticks in Brazil. Horses with access to forest or kept in paddocks were associated with the occurrence of anti-Rickettsia spp antibodies $(\mathrm{p}<0.01)$.

Keywords: Donkey, Horse, Piauí, Rickettsia 



\section{SUMÁRIO}

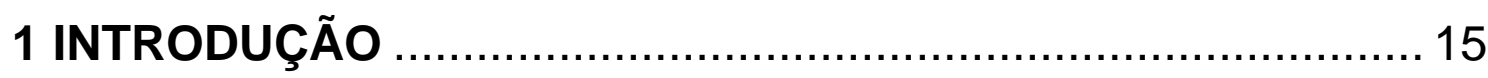

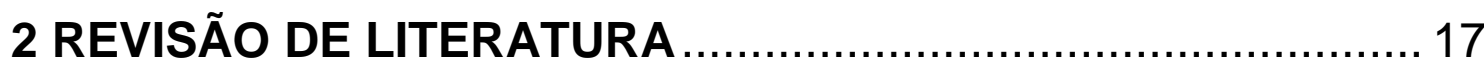

2.1 RIQUETTISIOSES POR Ricketsia spp. NO BRASIL E NO

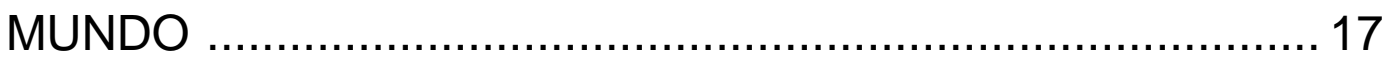

2.1.1 Microbiologia do gênero e taxonomia ............................... 17

2.1.2 Rickettisioses por Rickettsias do grupo da febre imaculosa .............................................................. 18

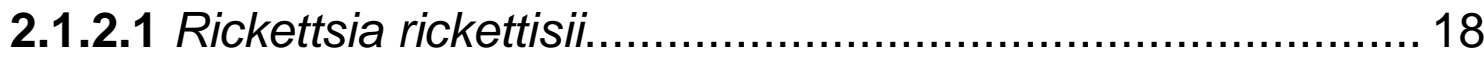

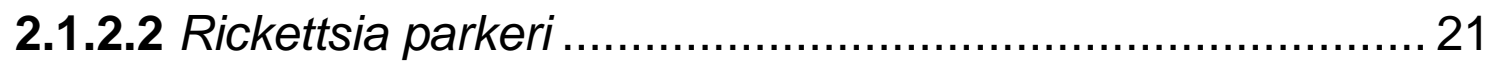

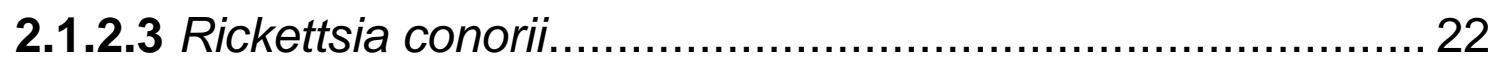

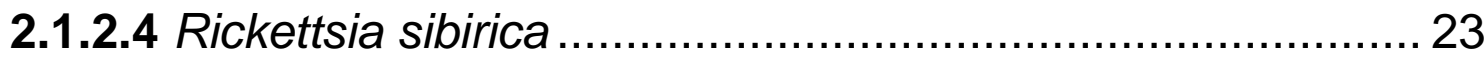

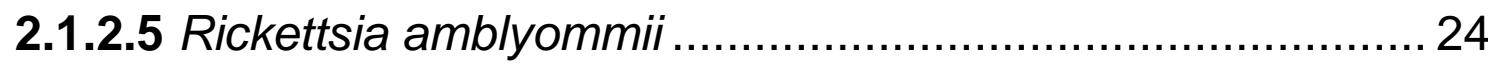

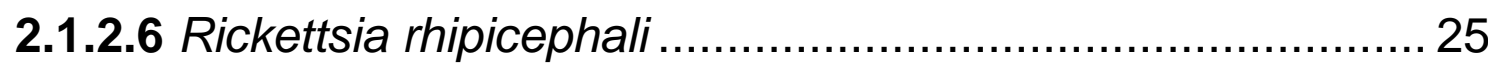

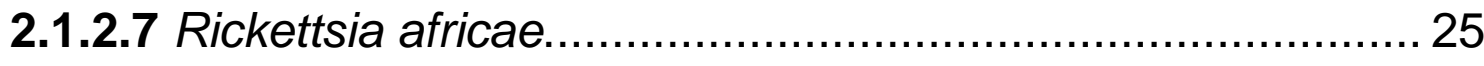

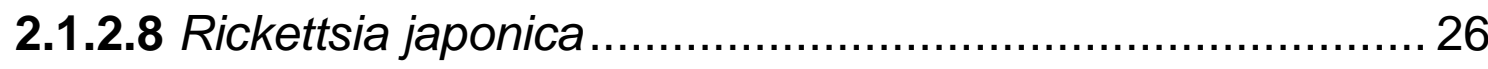

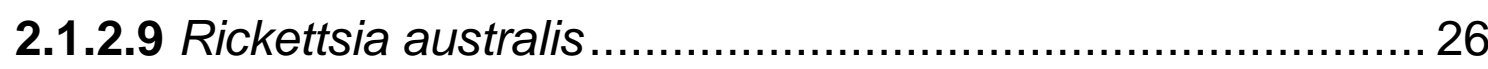

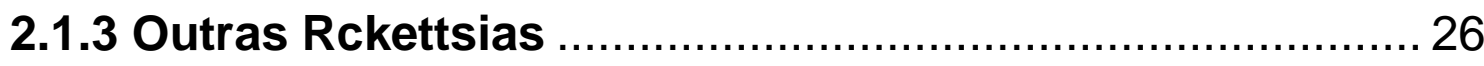

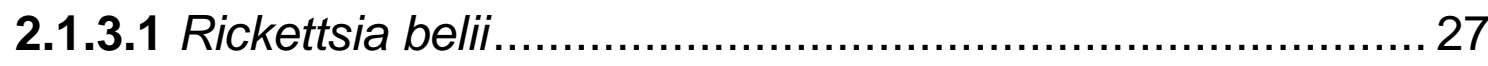

2.1.3.2 "Candidatus Rickettsia andeanae" ...................................... 28

2.2 VETORES E HOSPEDEIROS INVERTEBRADOS ................... 28

2.2.1 Taxonomia e biologia do carrapato …………………......... 29

2.2.2 Carrapatos e saúde pública .............................................. 30

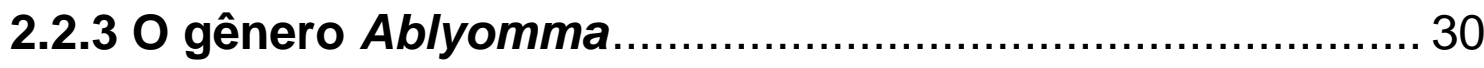

2.2.3.1 Amblyomma cajennense..................................................... 31 


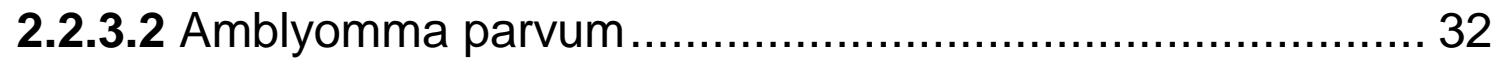

2.2.4 O gênero Dermacentor................................................ 33

2.2.4.1 Dermacentor nitens ....................................................... 33

2.3 RESERVATÓRIO E HOSPEDEIROS VERTEBRADOS ........... 34

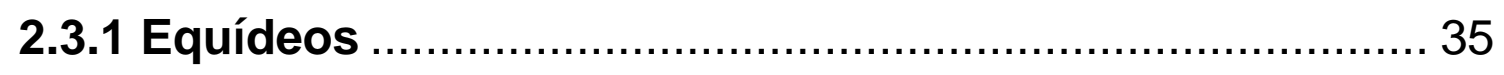

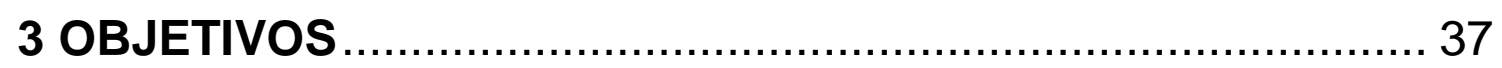

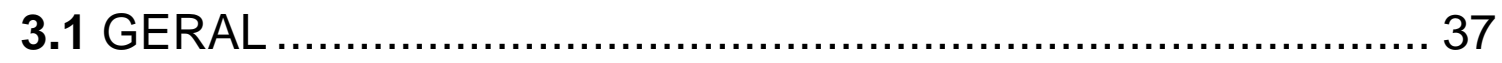

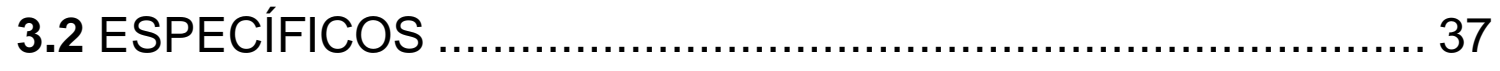

4 MATERIAL E MÉTODOS............................................... 39

4.1 ÁREAS DE ESTUDO................................................ 39

4.1.1 Microregião de Campo Maior...................................... 40

4.1.1.1 Campo Maior ........................................................ 40

4.1.1.2 Castelo do Piauí ............................................................... 41

4.1.2 Microregião de Teresina .......................................... 41

4.1.2.1 José de Freitas ........................................................ 42

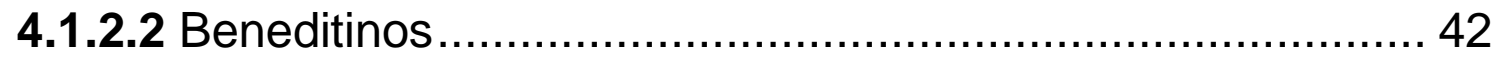

4.1.3 Microregião de Valença do Piauí .................................. 42

4.1.3.1 Elebão Veloso .......................................................... 43

4.2 COLETAS DE AMOSTRAS ............................................... 43

4.3 IDENTIFICAÇÃO DOS CARRAPATOS ................................ 45

4.4 EXTRAÇÃO DE DNA DOS CARRAPATOS .......................... 46

4.5 REAÇÃO EM CADEIA PELA POLIMERASE (PCR) ............... 46

4.6 ANÁLISES DOS PRODUTOS AMPLIFICADOS ..................... 47

4.7 PURIFICAÇÃO E SEQUENCIAMENTO DE NUCLETÍDEOS .. 47 
4.8 REAÇÃO DE IMUNOFLUORESCÊNCIA INDIRETA (RIFI) ..... 48

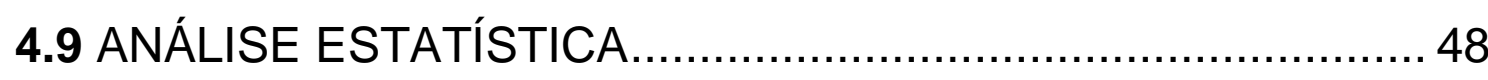

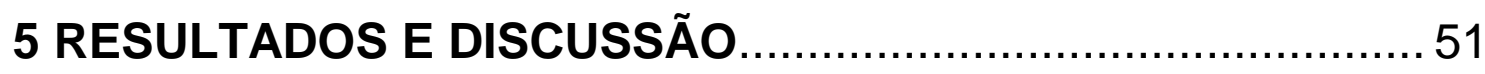

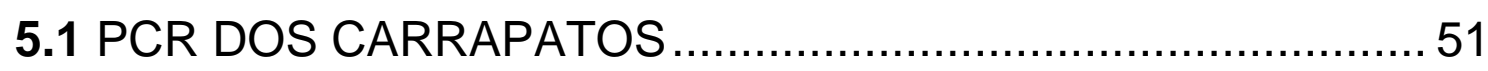

5.2 ANÁLISES DO SEQUENCIAMENTO GENÉTICO DAS AMOSTRAS POSITIVAS ................................................. 51

5.3 REAÇÃO DE IMUNOFLUORESCÊNCIA INDIRETA ...............55

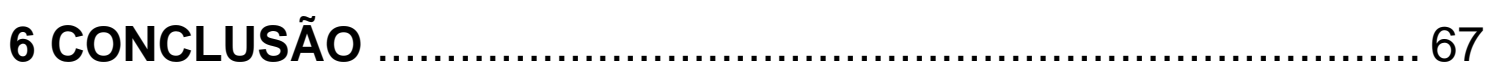

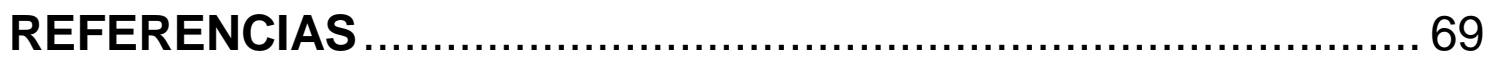





\section{INTRODUÇÃO}

São atuais os desafios enfrentados pela medicina veterinária e humana, em relação à emergência e reemergência de doenças transmitidas por artrópodes no Brasil e no mundo. Tanto os artrópodes, quanto as infecções por eles transmitidas, estão expandindo seus limites zoogeográficos devido a mudança climática e à maior acessibilidade a certos nichos ambientais (SHAW et al., 2001). O reflorestamento feito com arbustos e a prática agrícola de criar monocultura favorecem a proliferação de artrópodes, devido à formação de microclimas favoráveis, os quais geram um excelente habitat, viabilizando a sobrevivência dos ixodídeos nos mamíferos que são seus hospedeiros (CARDOSO et al., 2004) e, consequentemente, o surgimento das doenças por eles vetorizadas, com as rickettsioses.

Rickettsia spp. são bactérias intracelulares obrigatórias, pertencentes à família Rickettsiaceae e à ordem Rickettsiales (RAOULT; ROUX, 1997). As espécies deste gênero estão classicamente divididas em dois grupos, baseados nos padrões antigênicos moleculares e ecológicos, sendo demoninados como grupo do tifo (GT), composto pelas espécies Rickettsia prowazekii e Rickettsia typhi, transmitidas por piolhos e pulgas, respectivamente; as do grupo da febre maculosa (GFM), o qual está composto por mais de 23 espécies válidas, incluindo pelo menos 12 espécies que comprovadamente causam infecções no homem, como Rickettsia rickettsii, a de maior importância. A transmissão da grande maioria das espécies do GFM está associada a carrapatos, com exceção da Rickettsia felis e Rickettsia akari, associadas a pulgas e pequenos ácaros, respectivamente. Há ainda outras espécies de rickettsias, tais como Rickettsia bellii e Rickettsia canadenses, que não estão inseridas em nenhum destes dois grupos (YU; WALKER, 2003).

O carrapato Amblyomma cajennense é o vetor mais comum da febre maculosa brasileira (FMB) (DIAS; MARTINS, 1939; GUEDES et al., 2005) sendo a principal espécie de carrapato que parasita seres humanos no centro sul brasileiro. Equinos, capivaras e antas são considerados os principais hospedeiros para todos os estágios parasitários do $A$. cajennense no Brasil (LABRUNA et al., 2002) e os equinos assumem um considerável papel como sentinela da FMB em áreas onde 0 carrapato vetor é A. cajennense (SANGIONI et al., 2005). 
A importância crescente da equideocultura no nordeste bem como no estado do Piauí, tem sido observada com a introdução de raças de equinos de grande porte nos rebanhos locais, principalmente para atividades esportivas.

O jegue doméstico (Equus asinus vulgaris), também conhecido como asno ou jumento, originou-se do mesmo ramo filogenético dos cavalos. Dados paleontológicos relatam sua existencia a partir da era terciária, no período Paleoceno no Mar Adriático (TORRES; JARDIM, 1985). Equus. asinus atlanticus foi descrito como existente já na era quartenária na região argelina (RUMUSZKAN; JUNQUEIRA, 1980). O jegue é o animal eleito para executar uma ampla série de trabalhos nas regiões norte e nordeste do Brasil, devido a sua grande resistência física, quando comparado ao cavalo comum (TORRES; JARDIM, 1985). Esse animal é encontrado em todo o território nordestino sendo utilizado como meio de transporte em várias atividades rurais.

São poucos os estudos com equídeos referentes à doenças transmitidas por carrapatos na região nordeste brasileira. Informações sobre as espécies de carrapatos que infestam estes animais e das doenças por eles transmitidas, devem ser melhor estudadas. Por este motivo, este estudo foi idealizado a fim de avaliar a infecção por Rickttsia spp em carrapatos e em equídeos da região centro-norte do estado do Piauí. 


\section{REVISÃO DE LITERATURA}

\subsection{RIQUETTISIOSES POR Ricketsia spp. NO BRASIL E NO MUNDO}

Rickettsioses ja foram descritas em todo mundo, variando desde sinais clinicos aos vetores envolvidos na transmissão. Os topicos abaixo tratam das principais rickettsias e rickettsioses, ja relatadas no Basil e no Mundo.

\subsubsection{Microbiologia do gênero e taxonomia}

Rickettsias são bactérias que pertencem ao Filo das Proteobactérias, classe Alphaproteobactérias, ordem Rickettsiales, família Rickettsiaceae e gênero Rickettsia (GARRITY et al., 2004). Inseridas neste gênero estão as bactérias causadoras da febre maculosa, do tifo e da doença nomeada Orientia tsutsugamushi causada pela Rickettsia tsutsugamushi (TAMURA et al., 1995).

As rickettsias têm sofrido intensa reorganização taxonômica durante os últimos dez anos. A família Bartonellaceae foi removida da ordem Rickettsiales, enquanto Anaplasmataceae e Rickettsiaceae foram adicionadas. $\mathrm{Na}$ família Rickettsiaceae foram incluídos os gêneros Rickettsia e Orientia (DUMLER et al., 2001). Atualmente, o gênero Rickettsia classifica dois grupos distintos: O grupo do tifo (GT) que inclui $R$. prowazekii, agente do tifo endêmico e $R$. tiphy, agente causador do tifo murino. O grupo da febre maculosa (GFM), que compreende as conhecidas $R$. rickettsii, $R$. sibirica, $R$. rhipicephali, $R$. parkeri e todas as rickettisias associadas a carrapatos com exceção das $R$. felis $e$. akari, que estão associadas com pulgas e ácaros gamasida, respectivamente. $R$. belli e $R$. canadenses da mesma família Rickettsiaceae, ancestral, não fazendo parte nem do GT nem do GFM (PAROLA; PADDOCK; RAOULT, 2005; LABRUNA, 2009)

As rickettsias são microrganismos procarióticos, descritos como formas cocobacilares, pequenos bastonetes ou bacilos Gram-negativos, que retém fucsina 
básica quando corados pelo método de Gimenez, possuem citocromo e suas reações metabólicas são aeróbias. São parasitos intracelulares obrigatórios, multiplicam-se por fissão binária simples, colonizam e tem predileção por glândulas salivares e ovários de artrópodes hospedeiros, mas também infectam e se multiplicam em células dos intestinos, túbulos de malpighi e hemolinfa desses artrópodes (GIMENEZ, 1964; BURGDORFER, 1970; BILLINGS et al., 1998; WEISS; MOULDER, 1984; YU; WALKER, 2003). A parede celular é composta por peptideoglicano e lipopolissacarídeos (LPS). Os LPS estão presentes em todas as rickettsias do GFM e em pouca quantidade nas do GT. Por serem antígenos específicos das rickettsias do GFM os LPS têm papel na fixação do complemento e estão na origem das reações imunitárias cruzadas que ocorrem entre as diferentes rickettsias e entre essas e outras bactérias (BACELLAR, 1996).

A espécie humana é um hospedeiro acidental interrompendo, quando acometidos, o ciclo dessas bactérias, exceto pelo tifo exantemático, em que humanos constituem o reservatório (GALVÃO et al., 2005).

\subsubsection{Rickettisioses por Rickettsias do grupo da febre maculosa}

Os tópicos abaixo tratam das principais rickettsias do GFM, causadoras ou não de febres exantemáticas, transmitidas por carrapatos já relatadas no Brasil e ou no mundo.

\subsubsection{Rickettsia rickettisii}

Rickettsia rickettisii está restrita as Américas, e é o agente da Febre Maculosa das Montanhas Rochosas (FMMR), nome dado devido sua grande ocorrência nos estados americanos cortados pela cadeia das Montanhas Rochosas (Rocky Montain Spotted Fever), sendo também agente da Febre Maculosa Brasileira (FMB) (BRASIL, 2005). Considerada a mais patogênica dentre as rickettsias, tem causado mortalidade significativa nos Estados Unidos (PAROLA; PADDOCK; RAOULT, 2005) 
e no Brasil (Ministério da Saúde), além de vários casos distribuídos no continente ocidental.

Em 1899, Edward E. Maxey relatou pela primeira vez um caso clínico de FMMR, no Estado de Idaho, nos EUA, descreendo sinais clínicos similares aos de outras febres exantemáticas transmitidas por artrópodes. Howard T. Ricketts, em 1906, demonstrou a importância do carrapato na transmissão da FMMR isolando o agente Rickettsia rickettsii. A febre maculosa é clinicamente muito semelhante ao tifo. Em função dessa semelhança, Ricketts foi convidado a colaborar em pesquisas durante uma epidemia de tifo no México. Infelizmente, dias após isolar e identificar o microrganismo causador da doença, contaminou-se e veio a falecer de tifo em 1910 (HARDEN, 1985).

Segundo o Centro de Controle e Prevenção de Doenças (CDC) dos EUA, até 2006 em média, 750 novos casos anuais de FMMR foram registrado naquele pais, nos últimos 50 anos.

Oficialmente nos EUA, existem três espécies de carrapatos incriminadas na transmissão de $R$. rickettsii: Dermacentor variabilis, Dermacentor andersoni e Rhipicephalus sanguineus (CDC, 2006). Recentemente Amblyomma americanum também é apontado como vetor da FMMR nos EUA, (BERRADA et al., 2011).

Nas Américas Central e do Sul, infecções naturais com $R$. ricketsii também foram detectadas em $A$. cajennense coletados no Panamá, além de vários casos confirmados por métodos moleculares (ESTRIPEAUT et al., 2007). Em 2007 novos casos foram observados em Los Córdobas, na Colômbia (HIDALGO et al., 2011) além de vários outros relatos de febre maculosa no Canadá, México, Panamá, Costa Rica, Argentina, Colômbia e Brasil (DANTAS-TORRES, 2007).

No Brasil, a doença foi descrita pela primeira vez pelo médico e pesquisador José Toledo Piza, em 1929, em São Paulo, diferenciando a Febre Maculosa FM de outras doenças exantemáticas. A maioria dos casos de FMB se concentram na Região Sudeste, com casos esparsos em outros estados brasileiros, em especial do Sul do Brasil. Essa maior ocorrência coincide com a presença do principal vetor e reservatório, o carrapato estrela, $A$. cajennense. Estão ainda associadas à transmissão da FMB as espécies Amblyomma aureolatum e Amblyomma dubitatum (DEL FIOL et al., 2011).

A FMB tem sido registrada nos estados de São Paulo, Minas Gerais, Rio de Janeiro, Espírito Santo, Bahia, Santa Catarina e mais recentemente, a partir de 
2005, nos estados do Paraná, Rio Grande do Sul, Distrito Federal e Ceará.

Ministério da saúde comunica que no período de 2007 a 2009 foram notificados 4.294 casos de FMB no Sistema de Informação de Agravos de Notificação (SINAN), com confirmação de 313 casos da doença, com taxa de letalidade média de $25 \%$. A maioria dos casos que evoluíram para óbito ocorreu na região Sudeste do Brasil.

No Estado de São Paulo, no mesmo período, foram registrados 137 casos com maior acometimento em pacientes do sexo masculino (73\%), da faixa etária de 40 a 49 anos e letalidade média de 33,57\%. Os municípios de Campinas, Piracicaba e Pedreira têm apresentado o maior número de casos no estado. Em Minas Gerais, no período, ocorreu o registro de 35 casos, com maior acometimento em homens (80\%), de 20 a 29 anos e letalidade média de $54,28 \%$. As regiões com maior número de casos foram: Região Metropolitana, Vales do Rio Doce, Mucuri e Jequitinhonha. No Rio de Janeiro, foram confirmados 29 casos, com taxa de letalidade média de $41,37 \%$. Os casos têm ocorrido com maior frequência na região de Barra do Piraí e Petrópolis. No Espírito Santo, nesse mesmo período, foram registrados oito casos, sem registros de óbitos. Surtos ocorreram nos municípios de Pancas, Barra de São Francisco, Nova Venécia e Baixo Guandu (BRASIL, 2012).

A região Sul registrou casos confirmados a partir de 2003, em Santa Catarina. Nesse estado, entre os anos de 2007 a 2009, foram notificados 94 casos da doença com maior ocorrência nos municípios do Vale do Itajaí, sem registro de óbitos. O estado do Paraná apresentou casos em 2005 (dois casos), 2006 (três casos) e entre os anos de 2007 a 2009 (cinco casos), com registro de um óbito em 2009 no município de Andirá. Já o estado do Rio Grande do Sul apresentou quatro casos, de 2007 a 2009.

Na região Centro-oeste, o Distrito Federal confirmou um caso em 2005, com evolução para cura, e na região nordeste, o primeiro caso de FMB foi confirmado no ano de 2010, no estado do Ceará, porem sem informações sobre o caso (BRASIL, 2012).

O Estado de São Paulo, sozinho, responde por $45,1 \%$ de todos os casos notificados no país (1997 a 2009). Houve um aumento expressivo no número de casos em todos os estados até o ano de 2005, quando se atingiu um pico de 172 casos notificados. Atualizações do ano de 2009, mostraram esse número caindo, chegando a 55 casos em todo o país. Ainda não há uma explicação razoável para essa queda (DEL FIOL et al., 2011) . 
A FMB é doença de notificação compulsória (DNC), regulamentada pela Portaria no 2325/GM de dezembro de 2001.

Supõe-se que a doença no país seja decorrente de mais de uma espécie de Rickettsia, com diferenças nas apresentações clínicas, virulência e letalidade. São necessários esforços por parte da assistência médica, vigilância epidemiológica e rede laboratorial para que haja maior percentual de isolamento das espécies circulantes nas diferentes regiões do Brasil. (BRASIL, 2012).

\subsubsection{Rickettsia parkeri}

Rickettsia parkeri foi identificada pela primeira vez em 1937, quando o cientista R. R. Parker relatou o isolamento de uma bactéria que infectava o carrapato Amblyomma maculatum, no Texas, EUA. Mais tarde, Parker inoculou em cobaias, carrapatos infectados e verificou sinais parecidos com as doenças causadas pelas rickettsias do GFM. Somente em $2002 R$. parkeri foi reconhecida como patogênica para seres humanos, quando isolada em cultivo celular e identificada por biologia molecular a partir da biópsia da lesão originada por picada de carrapato em paciente oriundo do estado da Virgínia, EUA (PADDOCK et al., 2004).

Sangioni et al. (2005), em estudos preliminares, sugerem que $A$. cajennense propicia o crescimento e a sobrevivência da $R$. parkeri. Recentemente, DNA desta bactéria foi isolado de Amblyomma triste no Uruguai (VENZAL et al., 2004). Os mesmos autores encontraram A. triste infectado por R. parkeri no Brasil e Uruguai, responsável por rickettsiose humana. Segundo Romer et al. (2011) discutem casos na Argentina, nos quais $R$. parkeri foi considerada como agente patogênico.

Clinicamente a Febre Maculosa de Parkeri (FMP), como vem sendo chamada, difere da clássica, causada por $R$. rickettsii, por apresentar linfoadenopatia e uma lesão papular típica " tache noir", no local onde o carrapato fixou-se pela primeira vez (PADDOCK et al., 2004).

No Brasil R. parkeri foi relatada pela primeira vez em 2006 isolada do carrapato $A$. triste coletado do ambiente, na cidade de Paulicéia, estado de São Paulo, confirmado por isolamento em cultivo celular e métodos moleculares (SILVEIRA, 2006). 
Analises atuais, sugerem $R$. parkeri (Atlantic rainforest strain), sequencias de DNA obtidas de Amblyomma ovale, $A$. aureolatum e $R$. sanguineus, como uma nova cepa circulante em algumas áreas do Brasil, podendo inclusive ser o agente responsável por casos que ocorreram no estado de Santa Catarina (MEDEIROS et al., 2011).

\subsubsection{Rickettsia conorii}

Apontada pela primeira vez como entidade nosológica por Ricardo Jorge, em 1930. Estirpes do complexo $R$. conorii são os agentes responsáveis pelas doenças de características sazonais conhecidas como febre botonosa ou Febre EscaroNodular (FEN). È uma doença endêmica em Portugal e comum em países do Mediterrâneo, incluindo o norte da África e sul da Europa. (SOUSA et al., 2003).

O complexo $R$. conorii inclui quatro subespécies diferentes que podem ser distinguidos sorologicamente e por reação em cadeia pela polimerase (PCR): $R$. conorii conorii, agente etiológico da febre botonosa ou febre maculosa do mediterrâneo, na Europa e África do Sul; $R$. conorii indica agente do tifo indiano do carrapato, na Índia; $R$. conorii israelenses, causando o tifo israelense do carrapato, no sul da Europa e Oriente Médio e R. conorii caspiae que causa a febre maculosa de Astrakhan, na região norte do Mar Cáspio na Rússia (ZHU et al., 2005)

O carrapato $R$. sanguineus é o principal vetor e reservatório da $R$. conorii (SOUSA et al., 2003) embora o carrapato Haemaphysalis leachii e Rhipicephalus (Boophilus) microplus, também sejam capazes de transmitir os agentes (ZHU et al., 2005). Qualquer estágio (larva, ninfa ou adulto) do R. sanguineus pode parasitar o homem, mas o período de incubação da doença e o ciclo biológico do vetor indicam que as ninfas são o estágio responsável pelo maior número de casos de FEN (HERRERO et al., 1989; GILOT et al., 1990; WALKER; FISHBEIN, 1991).

A importação para o novo mundo do vetor $R$. sanguineus e sua adequação aos microclimas de peri-domicílios, canis e casas, viabiliza a sobrevivência do carrapato e manutenção da circulação da bactéria nas regiões, fato constatado pelos esporádicos casos na Europa Central e Norte, principalmente no final da primavera e no verão quando o vetor é mais ativo (PAROLA; RAOULT, 2001). A alta 
especificidade do $R$. sanguineus por cães explica a baixa ocorrência da doença em seres humanos, como observado em estudos realizados no Sul da França (PAROLA et al., 2005).

Casos autóctones em 1990 e novos casos suspeitos em 2000 foram relatados no Uruguai, contudo a dificuldade de diagnóstico pode mascarar a verdadeira prevalência da doença na região (DÍAZ, 2001). Martino et al. (2001) relataram casos com diagnóstico sorológico positivo para $R$. conorii na Argentina, entretanto os pacientes eram recém chegados da África do Sul.

A taxa de mortalidade em pacientes infectados por $R$. conorii é estimada em $2,5 \%$ dos casos com diagnóstico. Casos típicos apresentam febre alta e escaras negras no local da fixação do carrapato, com período de incubação de seis dias, em média, e início de sintomatologia abrupto. Em alguns casos, quando o local de fixação ocorre dentro da conjuntiva ocular, o paciente pode apresentar conjuntivite (ANTON et al., 2003; PAROLA et al., 2005 ). Após sete dias aparecem manchas maculo papulares envolvendo a palma da mão, sola do pé e face e geralmente o paciente se recupera sem nenhuma sequela.

Dois casos fatais de febre maculosa causada por $R$. conorii foram diagnosticados no Brasil, no entanto, considera-se que estes pacientes adquiriram a infecção em Portugal e África do Sul, apresentando sintomas depois que chegaram no Brasil (ALMEIDA et al., 2010; GEHRKE et al., 2010).

\subsubsection{Rickettsia sibirica}

A enfermidade causada pela $R$. sibirica é chamada de tifo siberiano, linfagite associada a rickettsioses (LAR) ou linfagite expansiva, devido ao aumento significativo dos linfonodos durante a infecção. Ocorre uma linfadenopatia dolorosa, que tem origem no local da lesão causada pela picada do carrapato vetor, Hyalomma asiaticum (FOURNIER et al., 2000, 2005).

Esta bactéria já foi isolada nos carrapatos Dermacentor marginatus, Dermacentor nuttali, Dermacentor silvarum, Dermacentor pictus, Dermacentor sinicus, Dermacentor auratus, Haemaphysalis concinna, Hyalomma wellingtoni e Hyalomma yeni. A enfermidade já foi descrita no norte da China, Mongólia, 
Paquistão e Rússia (SOUSA et al., 2003; FOURNIER et al., 2005). O período de incubação é de quatro a sete dias, quando inicia o aparecimento de febre alta, escara de inoculação pelo vetor, que posteriormente acompanha uma linfadenite, além de dor de cabeça, mialgia e distúrbios digestivos. Esta doença geralmente apresenta sintomatologia de caráter mediano e raramente ocorrem maiores complicações.

Em 1996 um caso de infecção por $R$. sibirica foi diagnosticado na França, e foi observado que tratava-se de uma subespécie, denominada Rickettsia sibirica mongolitimonae, descrito na Mongolia. Subsequentemente outros casos foram relatados em Portugal, África do Sul, Egito, Grécia e Espanha, com casos recentemente descritos em 2011 (IBARRA et al., 2012).

\subsubsection{Rickettsia amblyommii}

Foi isolada inicialmente no carrapato $A$. americanum no estado do Tennessee, EUA, em 1974. O papel desta bactéria como agente de doenças humanas foi sugerido por Parola et al. (2005) que observaram um grupo de 12 militares que apresentou febre mediana e anticorpos reativos para rickettsias do GFM. R. amblyommii Tem sido detectada em Amblyomma longirostre, A. cajennense e A. coelebs, do Oeste da Floresta Amazônica, da Bahia e de São Paulo. Também já foi detectada no nordeste da Argentina, em A. neumanni (LABRUNA et al., 2004 a, b; 2007 a, b) e em $A$. coelebs coletados de queixada na Guiana Francesa (PAROLA et al., 2007).

São diversas as especulações e pesquisas sobre o papel da R.amblyommii vetoriada pelo $A$. americanum, em relação a sua capacidade patogênica para o ser humano. Vários casos de pessoas que adoeceram após serem picados pelo carrapato foram relatados e estes pacientes, desenvolveram sintomatologia típica de febre maculosa, porem bem mais branda, muitas vezes excluindo a infecção por $R$. rickettsii (KARDATZKE et al., 1992; SANCHEZ et al., 1992; DASCH et al., 1993; CHILDS; PADDOCK 2003; PADDOK et al., 2004). Outros autores relatam que em áreas onde a prevalência de $R$. amblyommii é alta nos carrapatos, pessoas apresentaram altos títulos sorológicos para a bactéria, mas não apresentaram 
nenhum sintoma de FMMR (STROMDAHL et al., 2008; APERSON et al., 2008) $\mathrm{Na}$ Carolina do Norte, EUA, alguns casos de FMMR foram re-avaliados, indicando $R$. amblyommii como provável agente infeccioso causador do quadro clinico desses pacientes e tendo A. americanum como provável vetor (APPERSON et al., 2008). Outros estudos mostram que a bactéria pode também estar relacionada ao eritema migratório, chamado de STARS, antes atribuído a Borrelia lonestari (BILLETER et al., 2007).

\subsubsection{Rickettsia rhipicephali}

Em 1975, durante um estudo sobre rickettsiose no Mississipe, EUA, observou-se que a bactéria isolada de $R$. sanguineus de cães diferia sorologicamente de $R$. rickettsii e das demais rickettsias do grupo da FMMR isoladas na época, tendo sido denominada Rickettsia rhipicephali (BURGDORFER et al., 1975).

Análises moleculares já demonstraram infecção por $R$. rhipicephali em carrapatos $R$. sanguineus e Rhipicephalus haemaphysaloides adultos em Taiwan, na China (HSU et al., 2011). No Brasil esta rickettsia já foi encontrada infectando Haemaphysalis juxtakochi e sorologicamente pode estar associada a infecção em cães (LABRUNA et al., 2005 b; 2007a,b). Ate o momento, o caráter patogênico desta bactéria ainda permanece desconhecido.

\subsubsection{Rickettsia africae}

O gênero Amblyomma, em especial o Amblyomma variegatum, é o carrapato vetor da febre africana da picada do carrapato, e é causada pela Rickettsia africae. Essa doença é cada vez mais comum entre os viajantes que passam pela África. Aproximadamente $27 \%$ dos pacientes que apresentam quadros clínicos febris, após terem passado temporada em regiões da África Sub-Sahariana, estão infectados 
pela $R$. africae e com freqüência apresentam também cefaléia, mialgia, linfadenites e exantema cutâneo (USLAN; SAI, 2004).

\subsubsection{Rickettsia japonica}

Os primeiros três casos de infecção por Rickettsia japônica, que causa a doença conhecida como febre maculosa japonesa (FMJ), foram diagnosticados em 1984 no Japão. Os carrapatos dos gêneros Haemaphysalis sp e Dermacentor sp. são apontados como vetores desta rickettsia. Em outubro de 1996 foram confirmados 31 casos de FMJ na cidade de Tokushima, Japão. Os pacientes tiveram febre elevada aguda, cefaleia e exantema característico, 90\% tinham a lesão local, conhecida com "eschar", escara cutânea ou de inoculação. De 1984 a 1995, 144 casos de FMJ foram reportados pelo Instituto Nacional de Saúde do Japão (MAHARA, 1997). A ocorrência de FMJ também foi descrita na Coréia do Sul (CHUNG et al., 2006).

\subsubsection{Rickettsia australis}

A Febre Maculosa Australiana (FMA) é causada pela Rickettsia australis, transmitida pela picada do carrapato Ixodes holocyclus. Foi descrita pela primeira vez em 1946, quando 12 soldados contraíram a doença durante exercícios de treinamento, no norte de Queensland, Austrália. Os sintomas foram febre, cefaleia, mialgia, náusea, vômito, confusão mental, escara de inoculação, linfadenopatias e exantema máculo-papular. A escara de inoculação está presente na maioria dos casos e comumente é única (SOUSA et al., 2003).

\subsubsection{Outras rickettsias}

Fora do GFM, R. bellii e outras rickettsias ainda não classificadas, também são encontradas no território brasileiro e no mundo. 


\subsubsection{Rickettsia bellii}

Durante um estudo sorológico nos EUA, em áreas sabidamente ocorrentes de R. rickettsii, uma possível nova espécie de Rickettsia foi isolada de Dermacentor variabilis, e denominada cepa 369-C. Estudos posteriores demonstraram uma série de reações sorológicas cruzadas entre a cepa 369-C e várias bactérias tanto do GFM quando do GT. Posteriores estudos morfológicos e genotípicos permitiram classificar a cepa como uma nova espécie: Rickettsia bellii (PHILIP et al., 1983). Mais tarde estudos relativos aos genes 16s rRNA e 23s rRNA demonstraram evidencias de que a $R$. bellii poderia ser classificada em um grupo diferente do GT e do GFM com características ancestrais dos dois grupos dentro das alphaproteobacterias e Rickettsiaceae (STOTHARD et al., 1994). Até hoje permanece classificada como pertencente a um grupo ancestral separado, juntamente com $R$. canadenses (DUMLER et al., 2001).

$R$. bellii é considerada uma das rickettsias mais comumente observadas em carrapatos nos EUA e também no Brasil (LABRUNA et al., 2011). Encontrada em vários Ixodídeos, incluindo espécies de Dermacentor e Amblyomma, é também a única rickettsia encontrado em carrapatos moles e duros, portanto, exibindo a maior amplitude de hospedeiros artrópodes entre as rickettsias conhecidas (OGATA et al., 2006).

Até a atualidade, pouco se sabe sobre a capacidade patogênica dessa bactéria, apesar de infecções experimentais mostrarem alguns efeitos patogênicos em cobaias e coelhos (OGATA et al., 2006). Um estudo no estado de São Paulo em capivaras, demonstrou, pela primeira vez, evidencias sorológicas de infecção natural por $R$. bellii em vertebrados (PACHECO et al., 2007).

No Brasil esta rickettsia já foi encontrada em $A$. ovale, Amblyomma oblongoguttatum, Amblyomma scalpturatum, Amblyomma humerale e A. rotundatum em Rondônia (LABRUNA et al., 2004a) e no estado de São Paulo em $A$. aureolatum, A. dubitatum, A. ovale, Amblyomma incisum, Amblyomma nodosum, Ixodes loricatus e H. juxtakochi (PINTER; LABRUNA, 2006; LABRUNA et al., 2004b, 2007a; HORTA et al., 2007; OGRZEWALSKA et al., 2009; PACHECO et al., 2009).

$\mathrm{Na}$ Argentina, em Santiago del Estero, Amblyomma parvum também já foi encontrado albergando esta bactéria (TOMASSOLE et al., 2010). 
2.1.3.2 "Candidatus Rickettsia andeanae"

Blair e colaboradores, em 2004, publicaram um artigo que relata uma possível nova espécie de rickettsia, encontrada em $A$. maculatum e Ixodes boliviensis coletados numa região agraria andina no nordeste do Peru. Análises biomoleculares de sequenciamento de DNA, a partir da amplificação de fragmentos dos genes ompA e ompB e comparações genéticas, permitiram a conclusão de que tratava-se de uma nova bactéria pertencente ao GFM e sugeriu-se denominar "Candidatus Rickettsia andeanae", fazendo alusão à região andina onde foi realizado o estudo.

Mais tarde pesquisadores relataram outra nova possível Rickettsia, denominando-a "Rickettsia sp. cepa Argentina", a partir de estudos moleculares em A. parvum da província de Córdoba na Argentina ( PACHECO et al., 2007b) e em Santiago del Estero no semiárido argentino, analisando A. parvum e Amblyomma pseudoconcolor (TOMASSOLE et al., 2010). Labruna et al. (2011) em revisão sobre rickettsioses nas Américas, consideram os dois achados como referentes a mesma bactéria, convencionando-se citar o primeiro nome publicado em 2004, "Candidatus Rickettsia andeanae".

\subsection{VETORES E HOSPEDEIROS INVERTEBRADOS}

Várias espécies de artrópodes são apontadas como vetores de rickettsias. Os tópicos abaixo tratam sobre carrapatos e sua importância como hospedeiros e vetores das rickettsioses. 


\subsubsection{Taxonomia e biologia do carrapato}

Os carrapatos estão inseridos na ordem Acari, subordem Ixodida e representados por três famílias: Ixodidae, Argasidae e Nuttalliellidae. As famílias Argasidae e Ixodidae são amplamente distribuídas, enquanto que Nuttalliellidae está restrita à África do Sul e Tanzânia (BARROS-BATTESTI et al., 2006).

A família Ixodidae está representada por 14 gêneros e 702 espécies em dois grupos: Prostriata com 242 espécies, todas do gênero Ixodes, Latreille e Metastriata com 458 espécies acomodadas em 13 gêneros, a saber: Amblyomma, Anomalohimalaya, Bothriocroton, Compluriscutula, Cornupalpatum, Cosmiomma, Dermacentor, Haemaphysalis, Hyalomma, Margaropus, Nosomma, Rhipicentor e Rhipicephalus (GUGLIELMONE et al., 2010; GUGLIELMONE; NAVA, 2011). O mais recente levantamento brasileiro lista a existência de 61 espécies em nove gêneros sendo, 41 espécies da família Ixodidae e 17 espécies da família Argasida (DANTASTORRES et al., 2009).

Os ixodídeos, conhecidos como "carrapatos-duros", são parasitos de vertebrados em geral, mas alimentam-se preferencialmente em mamíferos, dos quais Rodentia é o táxon mais parasitado (WOOLLEY, 1988; OLIVER, 1989). Quando em fase não parasitária (entre mudas), são encontrados nos mais variados ambientes. O ciclo biológico dos ixodídeos compreende ovo, larva, ninfa e adulto com dimorfismo sexual acentuado. Cada estágio requer apenas uma única alimentação, com longos repastos sanguíneos que duram vários dias nos hospedeiros. As fêmeas sugam de uma única vez grande quantidade de sangue para a produção de milhares de ovos colocados numa única oviposição, morrendo em seguida. Geralmente, os machos alimentam-se intermitentemente, permanecendo no hospedeiro por semanas ou meses (OLIVER, 1989).

Carrapatos são capazes de permanecer fixados e exercendo a hematofagia por vários dias, apesar das reações do hospedeiro. Isso deve-se ao fato de possuírem em sua saliva, substâncias anti-hemostáticas, anti-inflamatórias e imunossupressoras (TITUS et al., 2006; PARIZI; MASUDA; JUNIOR, 2007). Peterková et al. (2008) demonstraram que a saliva de algumas ninfas de carrapatos (Dermacentor reticulatus, Ixodes ricinus, Rhipicephalus appendiculatus e $A$. variegatum), possui um arsenal imunorregulatório, que modula as atividades de 
diversas citocinas de seus hospedeiros. Essas propriedades da saliva também favorecem a inoculação e a transmissão de vários patógenos (RANDOLPH; CRAINE, 1995).

\subsubsection{Carrapatos e saúde pública}

Cerca de 879 espécies válidas de carrapatos já foram descritos em todo o mundo. Entretanto apenas cerca de 90 destas espécies tem importância em Saúde Pública (OLIVER, 1989). Devido às particularidades de seus hábitos alimentares, os carrapatos constituem o principal grupo de vetores em saúde pública. Eles podem transmitir uma grande variedade de agentes patogênicos e ainda causar paralisias, dermatites e alergias (JONGEJAN; UILENBERG, 2004).

Quanto à transmissão de doenças, é importante observar que carrapatos são capazes de permanecer por meses no meio ambiente esperando um hospedeiro no mesmo lugar, isso garante um foco de doenças prolongado. Considerando a longevidade excepcional destes ácaros eles se tornam não apenas vetores, mas também reservatórios de agentes infecciosos (LABUDA; NUTTALL, 2004).

Em animais, estes artrópodes são responsáveis pela transmissão de algumas das doenças infecciosas mais prevalentes do Brasil como a erliquiose canina e a babesiose bovina.

\subsubsection{O gênero Amblyomma}

Na região do neotrópico, que compreende as ilhas caribenhas, sul do México e as Américas Central e do Sul, existem 188 espécies de carrapatos descritas, das quais 59 são do gênero Amblyomma Kock 1844, das quais 47 são exclusivas, 11 ocorrem também na região Neártica e apenas uma não é autóctone das Américas.

No Brasil a fauna de Ixodídeos está atualmente representada por 61 espécies, com o gênero Amblyomma representando o maior número dentre estes (BARROS-BATTESTI et al., 2006) A distribuição geográfica do gênero Amblyomma 
é extensa, abrangendo quase todos os continentes. As únicas exceções são a Europa e a Antártida (ONOFRIO et al., 2006). Aproximadamente 130 espécies já foram descritas para este gênero em todo o mundo (GUGLIELMONE et al., 2010). Diversas espécies desse gênero são reconhecidas como vetores de patógenos que tanto acometem os humanos como os animais de produção (GUGLIELMONE et al., 2003, 2006).

O gênero Amblyomma é o de maior importância médica, já que inclui as principais espécies que parasitam humanos. Dentre elas, destacam-se $A$. aureolatum, $A$. cajennense e $A$. ovale, que são incriminados na transmissão da FMB e outras rickettsioses para humanos (LABRUNA, 2004; GUEDES et al., 2005; PINTER; LABRUNA, 2006; SABATINI et al., 2010; SPOLIDORIO et al., 2010).

\subsubsection{Amblyomma cajennense}

A espécie Amblyomma cajennense, carrapato nativo da América do Sul, é a espécie de maior importância em diversos países (SZABÓ, 2009a). No estado de São Paulo $A$. cajennense assume destacada importância (GUEDES et al., 2005) juntamente com A. aureolatum como vetores da FMB (PINTER; LABRUNA, 2006).

Biologicamente para que haja estabelecimento desta espécie numa região é necessário a presença de pelo menos uma das espécies consideradas como hospedeiros primários para a fase adulta do carrapato. No Brasil consideram-se como hospedeiros primários para $A$. cajennense as antas, as capivaras, os cavalos e provavelmente os queixadas (LABRUNA et al., 2001,2005c ) No entanto $A$. cajennense possui uma extensa gama de outros possíveis hospedeiros, incluindo mamíferos, aves e cobras (ARAGÃO, 1936; ROJAS et al., 1999; CAMPOS PEREIRA et al., 2000; LABRUNA et al., 2002a; GUGLIELMONE et al., 2003; SZABÓ et al., 2007). Estudos relativos à sazonalidade das fases do ciclo de vida do $A$. cajennense, apontam maior atividade larval no outono, de ninfas no inverno e de adultos na primavera e verão (LABRUNA et al., 2002)

Guglielmone et al. (2006) descreveram várias localidades onde esta espécie foi encontrada parasitando humanos, sendo muitos os casos relatados na Argentina, 
Bolívia, Brasil, Colômbia , Equador, Guiana Francesa, Guiana, Paraguai, Suriname e Venezuela.

Com exceção das florestas tropicais $A$. cajennense pode ser encontrado em todos os biomas do país (SZABÓ et al., 2007).

\subsubsection{Amblyomma parvum}

Alguns autores tem observado A. parvum em vários hospedeiros (JONES et al, 1972.; PEREIRA et al., 2000; MARTINS et al, 2004; LABRUNA et al, 2005b), porém nenhum deles afirmou ou sugeriu uma espécie de animal que possa ser considerada como hospedeiro primário desse carrapato. A ocorrência deste carrapato já foi registrada em animais domésticos (cães e equinos e bovinos) e $A$. parvum também demonstrou ser bastante agressivo ao homem (NAVA et al., 2006a; SZABÓ et al., 2007). Nava et al. (2006b) afirmam que na Argentina, larvas e ninfas dessa espécie, dependem de roedores cavídeos para completar seu ciclo de vida na natureza e que adultos de $A$. parvum são comuns em bovinos e cabras. No Paraguai, Durden et al. (2006), descreveram infestações por $A$. parvum em felídeos selvagens. Fiorello et al., (2006) no Chaco boliviano, registraram essa espécie de carrapato em pequenos carnívoros, como cachorro do mato (Cerdocyon thous) e raposinha (Pseudalopex gymnocercus).

A. parvum é encontrado como parasita regular de bovinos no norte da Argentina, inferindo a predileção desse carrapato por regiões mais secas, onde também são descritos parasitando humanos, podendo ser considerados um potencial vetor para zoonoses (GUGLIELMONE; HADANI, 1982; GUGLIELMONE et al., 1990, GUGLIELMONE et al., 1991b; GUGLIELMONE et al., 2006).

No Brasil, adultos desta espécie já foram encontrados parasitando diversas ordens de mamíferos. Segundo Pereira et al. (2000) A. parvum já foi encontrado no Pantanal brasileiro em veado-catingueiro (Mazama gouzoubira) e em quatis (Nasua nasua). Martins et al. (2004) registraram A. parvum em tamanduá-bandeira (Mymercophaga trydactyla) e tamanduá-mirim ( Tamandua tetradactyla) na região do Pantanal Mato-Grossense. Saraiva et al. (2011), em Minas Gerais, encontraram A. parvum em vários roedores. Estudos no cerrado brasileiro na região de Goiás, 
verificaram este carrapato em duas áreas de vida selvagem, em pastagens, em animais domésticos, principalmente cães e equinos, e ainda em seres humanos (SZABÓ et al., 2007). Labruna et al. (2005b), em revisão sobre carrapatos de hospedeiros carnívoros, constataram a presença desse ácaro em sete espécies de hospedeiros. A. parvum, à semelhança do $A$. cajennense, parece ser capaz de se fixar e parasitar uma ampla gama de animais domésticos, selvagens e até humanos. Esta promiscuidade parasitária torna o $A$. parvum um potencial veiculador de patógenos entre hospedeiros, inclusive o homem.

No Brasil, desconhece-se o envolvimento do $A$. parvum com alguma doença. Segundo as observações de Szabó et al. (2007), o número elevado de A. parvum na vegetação, em diversos animais domésticos e em seres humanos, indica que este carrapato tem capacidade de se tornar uma espécie parasita importante de hospedeiros domésticos e com potencial zoonótico.

\subsubsection{O gênero Dermacentor}

O gênero Dermacentor está representado por oito espécies na região Neotropical, sendo quatro exclusivas. No entanto somente Dermacentor imitans, cuja distribuição vai desde o sul do México ate a Venezuela e D.nitens, com ampla distribuição desde a região Neártica até a Argentina (exceto Chile e Uruguai), alcançam a América do Sul. A maioria das espécies são trioxenas, porem $D$. nitens e D. albipictus são carrapatos monoxenos (BARROS-BATTESTI et al., 2006).

\subsubsection{Dermacentor nitens}

Dermacentor nitens Neumann, 1897, (Acari: Ixodidae) é primariamente um ectoparasita de cavalos e outros equídeos, encontrado em todo o Brasil (FALCE et al., 1983; BORGES; LEITE, 1998). É um carrapato de um único hospedeiro (monóxeno), parasitando particularmente o pavilhão auricular, divertículo nasal, crina 
e regiões perianais. Infestações podem causar lesões graves no ouvido e predispor o hospedeiro a infecções secundárias e infestações por moscas e mutucas. D. nitens é também o vetor de Babesia caballi, agente da babesiose equina no novo mundo (ROBY; ANTHONY, 1963).

Apesar de incomum É pouco provável que rickettsias parasitem esta espécie de carrapato. Bermudez et al. (2009) encontraram DNA de R. rickettsi em um D. nitens retirado de cavalo em Santa Fé, na província de Darien, Panamá.

\subsection{RESERVATÓRIOS E HOSPEDEIROS VERTEBRADOS}

Segundo a Associação Americana de Saúde Pública (American Association at Public Health), reservatórios são definidos como qualquer ser humano, animal, artrópode, plantas ou matéria inanimada onde vive e se multiplica um agente infeccioso, da qual depende para sua sobrevivência, reproduzindo-se de maneira a que consiga ser transmitido a um hospedeiro suscetível. Hospedeiro é definido como pessoa, ou animal, inclusive aves e artrópodes que, em circunstâncias naturais, permitem a subsistência ou alojamento do agente infeccioso (AVILA-PIRES, 1989).

Para que um vertebrado seja considerado um bom hospedeiro amplificador de $R$. rickettsii na natureza, deve ser susceptível à infecção, manter a bactéria circulante em níveis plasmáticos suficientes para infectar vetores, ter alta taxa de renovação populacional, ser abundante na área endêmica e ser bom hospedeiro do carrapato vetor em condições naturais.

Equídeos, roedores, como a capivara (Hydrochaeris hydrochaeris), e marsupiais, como o gambá (Didelphis spp.), têm importante participação no ciclo de transmissão da FMB e há estudos recentes sobre o envolvimento desses animais como reservatórios ou amplificadores de Rickettsia spp, assim como transportadores de carrapatos potencialmente infectados. Equinos e cães, que vivem no peridomicílio humano, são considerados animais sentinelas para FMB, atuando também como amplificadores da população de carrapatos (CARDOSO et al., 2006; LABRUNA, 2009; PINTER et al., 2008). 


\subsubsection{Equídeos}

Os equinos assumem um considerável papel como sentinela da FMB em áreas onde o carrapato vetor é $A$. cajennense (SANGIONI et al., 2005).

$O$ jegue doméstico (Equus asinus vulgaris) originou-se do mesmo ramo filogenético dos cavalos. Dados paleontológicos relatam sua existencia a partir da era terciária, no período Paleoceno no Mar Adriático (TORRES; JARDIM, 1985). $E$. asinus atlanticus foi descrito como presente na era quaternária na região argelina (RUMUSKAN; JUNQUEIRA, 1980).

O jegue é o animal eleito para executar uma ampla série de trabalhos nas regiões norte e nordeste do Brasil devido a sua grande resistência física, quando comparado ao cavalo comum. Seu maior valor, entretanto esta na sua capacidade de hibridiar-se com a égua, produzindo o muar ou mula, que tem grande valia nas regiões tropicais e subtropicais, onde subistitue, com vantagem, equinos e asininos, reunindo a força e tamanho do equino e a resistência do asinino (TORRES; JARDIM, 1985). Sabe-se que asininos são mais resistentes a infestações por $A$. cajannense que cavalos (CASTAGNOLLI et al., 2003). Entretanto, estudos com o objetivo de conhecer melhor as espécies de carrapatos que infestam esses animais nessa região, ainda não foram feitas.

Lemos et al. (1996), em estudos no municipio de Pedreira (SP), região endemica para FMB, sugeriram que, além dos cães, os equinos tambem podem servir como animais sentinela para FMB. Estes autores observaram 77,8\% (7/9) de equinos sororeativos na RIFI para $R$. rickettisii. Sangioni et al. (2005) relataram que as áreas onde $A$. cajennense é o principal vetor da FMB, os equinos destacam-se como sentinelas por serem estes os hospedeiros primários de todos os estágios desta espécie de Ixodídeo. No mesmo trabalho, sorologia de RIFI para anticorpos anti- $R$. rickettisii mostraram soropositividade variando de 57,1\% a $90 \%$ em fazendas de áreas endêmicas e negatividade nas áreas não endêmicas do estudo. Os carrapatos $A$. cajennense testados foram negativos para análises moleculares para rickettsias.

Vianna et al. (2008), estudando carrapatos e sorologia em equídeos na Vila do Capoeirão, Itabira (MG), obtiveram 100\% (11/11) de positividade por meio da Reação de Imunofluorescência Indireta (RIFI), para anticorpos anti- $R$. rickettisii em 
equinos, porem observaram resultados positivos para as análises moleculares nos carrapatos da espécie $A$. cajennense (356) coletados dos animais e ambiente .

Moraes-Filho et al. (2009) investigaram a presença de $R$. ricketsii em equinos, encaminhados ao Centro de Controle de Zoonose do município de São Paulo (CCZ/SP) no período de 2003 a 2005. De 363 equinos avaliados pela RIFI, 64 $(17,6 \%)$ se mostraram reagentes à antigenos de $R$. rickettsii. Com a baixa sororreatividade das amostras e sabendo-se que $A$. cajennense é apontado como principal vetor da FMB na região de São Paulo, os autores sugerem que esta espécie possa não ser a responsável pela transmissão da FMB nesse município.

Em estudo realizado em seis haras localizados nos municípios de Cambé, Santa Fé, Guaraci e Londrina, Paraná, foi reportado anticorpos de equinos reagindo sorologicamente para antígenos de $R$. rickettsii (15/273) com títulos quatro vezes maiores do que os observadors para $R$. parkeri, sugerindo que estes animais podem ter sido expostos a uma rickettsia idêntica ou muito próxima a $R$. rickettsii (TAMAKUNI et al., 2010). Em Almirante Tamandaré- PR, região não endêmica para rickettsioses, outro estudo envolvendo cavalos e carrapatos, demonstrou reação sorologica de RIFI positiva para Rickettsia rickettisii em $8,45 \%$ dos cavalos (6/71) e negatividade nas análises moleculares nos carrapatos das espécies $D$. nitens e $A$. aureolatum (BATISTA et al., 2010). Estudos recentes em Juiz de Fora (MG), região endemica para FMB, demonstraram sorologia de RIFI positivas para equinos em $41.0 \%$ das amostras (16/39), para antigenos de $R$. rickettsii (PACHECO et al., 2011). 


\section{OBJETIVOS}

\subsection{GERAL}

Avaliar sorológico e molecularmente a ocorrência de infecção por Rickettsia spp em equídeos e carrapatos da região Centro-Norte do estado do Piauí.

\subsection{ESPECÍFICOS}

- Avaliar a frequência de anticorpos anti-Rickettsia spp em equinos e em asininos pela Reação de Imunofluorescência Indireta (RIFI);

- Identificar as espécies de carrapatos coletados nos equinos e asininos da mesoregião centro-norte do Piauí;

- Pesquisar Rickettsia spp nos carrapatos coletados por meio da Reação em Cadeia pela Polimerase (PCR) e

- Determinar os fatores de risco associados às infecções causadas por Rickettsia spp nos equídeos da região 


\section{MATERIAL E MÉTODOS}

Os tópicos abaixo definem os materiais e métodos de estudo, utilizados nesta pesquisa.

\section{1 ÁREAS DE ESTUDO}

O Estado do Piauí está localizado na parte oeste do Nordeste brasileiro, com uma área de $252.358 \mathrm{~km}^{2}$, representando $2,95 \%$ do total do território nacional. Abrange quatro mesorregiões geográficas: Norte, Centro-norte, Sudeste e Sudoeste (Figura 1) que se encontram subdivididas em 15 microrregiões geográficas, compreendendo um total de 223 municípios. Em função de seu posicionamento entre o nordeste semiárido e o meio-norte úmido, o Piauí apresenta diferenças climáticas entre algumas regiões: clima quente e úmido no norte, sul e sudoeste e clima semiárido no leste, centro-sul e sudeste, segundo esquema climático descrito por Koeppen (PEEL; FINLAYSON; MCMAHON, 2007).

O projeto foi desenvolvido na mesorregião centro-norte do estado do Piauí, coletando-se amostras, por conveniência, de carrapatos e sangue de equídeos das microrregiões: Campo Maior, Teresina e Valença do Piauí. 
Figura-1 Estado do Piauí e representação das mesorregiões (A,B,C,D) e microrregiões $(1,2,3,4)$

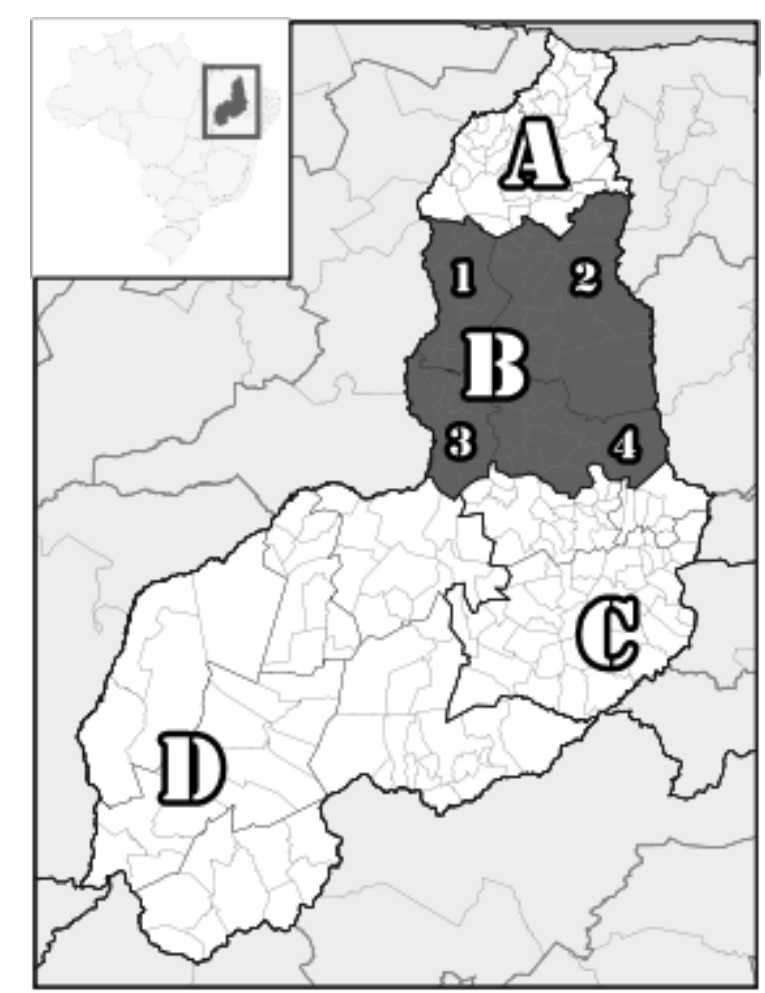

Legenda: A - Norte, B - Centro-norte, C - Sudeste, D - Sudoeste; 1 - Teresina, 2 - Campo Maior, 3 - Médio Parnaíba Piauiense, 4 - Valença do Piauí.

\subsubsection{Microrregião de Campo Maior}

Foram realizadas coletas em localidades de dois municípios na microrregião de Campo Maior: Campo Maior e Castelo do Piauí.

\subsubsection{Campo Maior}

O município de Campo Maior, dentro da microrregião que leva o mesmo nome, possui clima Tropical alternadamente úmido e seco, com duração do período seco de seis meses, temperatura média variando entre $26^{\circ} \mathrm{C}$ a $35^{\circ} \mathrm{C}$, vegetação do tipo parque e campo cerrado, precipitação pluviométrica de $1.302,4 \mathrm{~mm}$ e latossolos 
vermelho-amarelo podzólicos associados a areias quartzosas e solos indiscriminados tropicais (CEPRO-PI 2012). Neste município foram realizadas coletas em equídeos de três localidades: Fazenda Passarela (S0493'15"; O42 $10^{\prime} 42^{\prime \prime}$ ), com bovinocultura de corte, caprinocultura, ornicultura, suinocultura e equideocultura (cavalos e asnos). Haras Santo Antônio (S0485'94"; O42²1'31"), com atividades de caprinocultura e equinocultura esportiva e Correição da Associação dos Criadores do Piauí (ADAPI) que recebem animais do município de Campo Maior (S0449'40"; O42¹0’07”).

\subsubsection{Castelo do Piauí}

O município de Castelo do Piauí possui clima Tropical alternadamente úmido e seco, com duração do período seco de seis meses. Temperatura média, variando entre $26^{\circ} \mathrm{C}$ a $35^{\circ} \mathrm{C}$, vegetação do tipo campo cerrado, com manchas de cerradão e caatinga arbórea e arbustiva, precipitação pluviométrica de $1.042,3 \mathrm{~mm}$ e solos Podzólicos vermelho-amarelo distróficos associados a solos indiscriminados concrecionários tropicais e areias quartzosas distróficas (CEPRO-PI 2012). Neste município foi realizada coleta na localidade Canto do Saco (S05¹9'20"; O41³3'09"), entre criadores de equídeos para uso domestico e subsistência.

\subsubsection{Microrregião de Teresina}

Foram realizadas coletas em localidades de dois municípios na microrregião de Teresina: José de Freitas e Beneditinos. 


\subsubsection{José de Freitas}

O município de José de Freitas possui clima Tropical alternadamente úmido e seco, com duração do período seco de seis meses. Temperaturas médias entre $22^{\circ} \mathrm{C}$ a $37^{\circ} \mathrm{C}$, vegetação do tipo parque, floresta decidual secundária mista e babaçual, precipitação pluviométrica $1.484,7 \mathrm{~mm}$ e solos Latossolos vermelhoamarelo, associados a areias quartzosas distróficas, solos hidromórficos e podzólico vermelho-amarelo abruptos (CEPRO-PI 2012). Foi realizado coleta no Haras Nazaré (S0476'91"; $\left.042^{\circ} 58^{\prime} 44^{\prime \prime}\right)$ especializado em equideocultura esportiva.

\subsubsection{Beneditinos}

O município de Beneditinos (S05²7'21'; O42²1'37”) apresenta clima Tropical alternadamente úmido e seco, com duração do período seco de seis meses, ocorre ainda o clima sub-úmido quente a oeste do município, temperaturas médias entre $25^{\circ} \mathrm{C}$ a $36^{\circ} \mathrm{C}$, vegetação do tipo parque, campo cerrado e babaçual, precipitação pluviométrica $1.429,7 \mathrm{~mm}$ e solos latossolos vermelho-amarelo distrófico associados à podzólicos vermelho-amarelo abrupto, solos hidromórficos e solos concrecionários tropicais (CEPRO-PI 2012). Neste município foram realizadas coletas em duas localidades: As propriedades Graciosa e Porto Alegre, com animais criados para atividades de subsistência.

\subsubsection{Microrregião de Valença do Piauí}

Foi realizado coleta apenas em localidades do município de Elesbão Veloso nesta microrregião 


\subsubsection{Elesbão Veloso}

O município de Elesbão Veloso possui clima Tropical semiárido quente, com duração do período seco de seis meses, temperaturas médias entre e $25^{\circ} \mathrm{C}$ a $36^{\circ} \mathrm{C}$, vegetação do tipo Caatinga arbórea e arbustiva com manchas de campo cerrado, precipitação pluviométrica $1.171,5 \mathrm{~mm}$, e solos litólicos associados a solos indiscriminados concrecionários tropicais e latossolos vermelho - amarelo distróficos (CEPRO-PI 2012). Coletas foram realizadas em três povoados deste município:

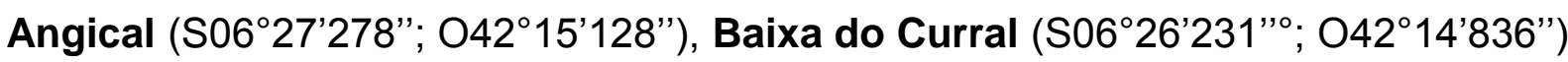

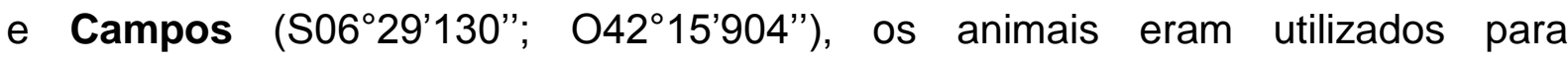
competições esportivas reprodução e subsistência.

\subsection{COLETAS DE AMOSTRAS}

As coletas foram realizadas nos meses de agosto dos anos de 2010 e 2011, que correspondem ao início do período seco. Utilizando tubos a vácuo e agulhas descartáveis, o sangue foi colhido da veia jugular dos equídeos. Depois das coletas o sangue foi centrifugado para obtenção do soro que em seguida foi armazenado em microtubos e estocado a $-20^{\circ} \mathrm{C}$ até a realização das análises.

Foram coletados, nos equídeos do estudo, todos os carrapatos que puderam ser encontrados parasitando os animais na ocasião das visitas. Os carrapatos foram colocados em microtubos, submersos em etanol absoluto e armazenados à temperatura ambiente para posterior identificação morfológica e análise biomolecular.

Amostras de soro foram obtidas de 239 equídeos (Tabela 1) e parasitando estes animais, um total de 692 carrapatos (Tabela 2) foram coletados Todas as análises foram realizadas no Laboratório de Doenças Parasitárias do Departamento de Medicina Veterinária Preventiva e Saúde Animal (VPS) da Faculdade de Medicina Veterinária e Zootecnia (FMVZ) da Universidade de São Paulo (USP). 
Não houve possibilidade de coletas na microrregião do Médio Parnaíba Piauiense e não foram encontrados carrapatos nos equídeos da microrregião de Valença do Piauí (Tabela 2/ Figura 2) quando das visitas.

Figura 2 - Microrregiões e localidades de procedência das amostras dos equídeos

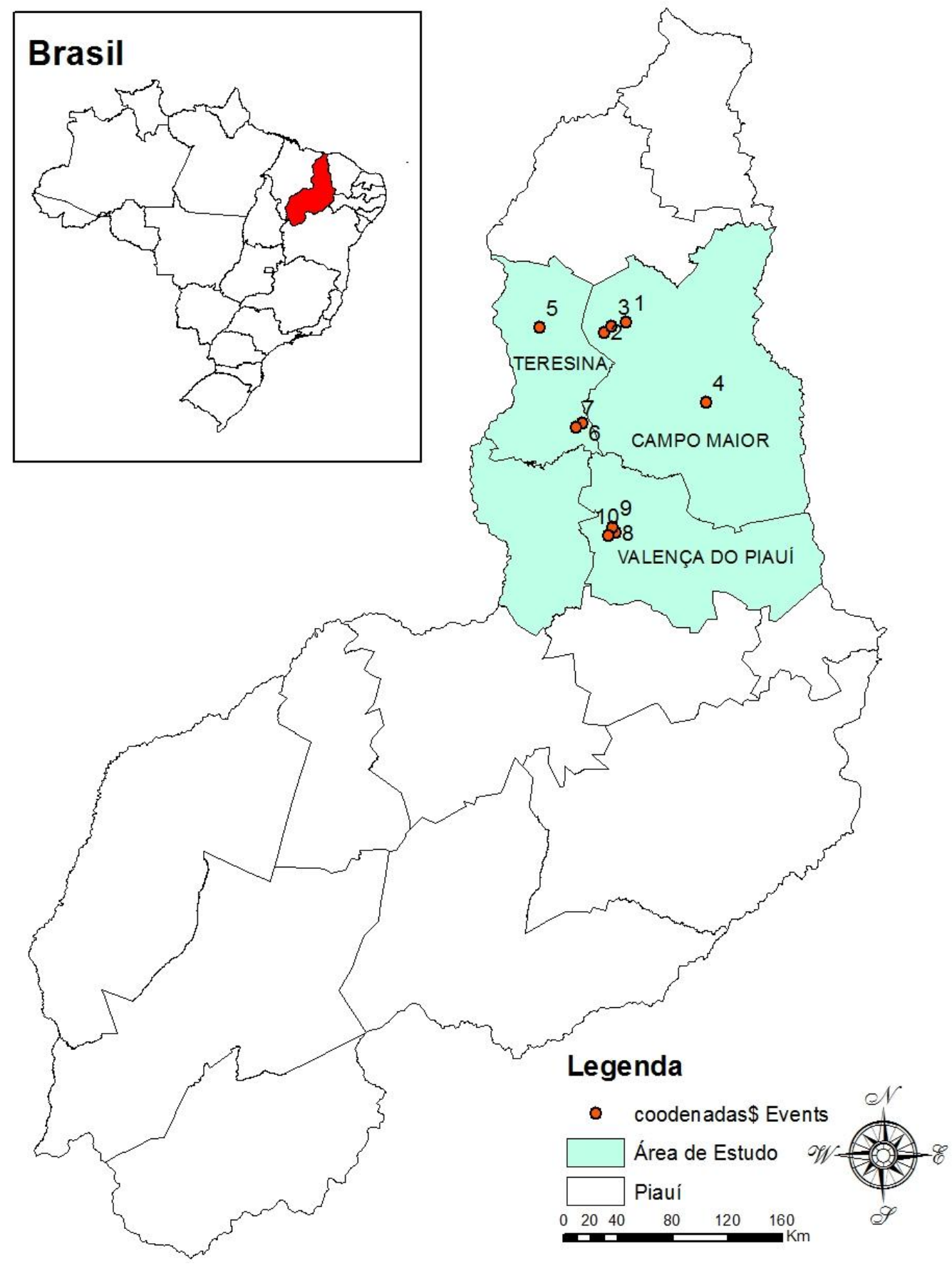

Legenda: 1- Fazenda Passarela, 2- Haras Santo Antônio, 3- Correição ADAPI, 4- Canto do Saco, 5Haras Nazaré, 6- Graciosa, 7-Porto Alegre, 8- Baixa do Curral, 9- Campos, 10- Angical 
Tabela 1 - Número de equinos e asininos amostrados por microrregião, município e localidade no estado do Piauí nos meses de agosto de 2010 e 2011

\begin{tabular}{|c|c|c|c|c|c|c|c|c|c|c|c|}
\hline \multirow[b]{2}{*}{ Municípios } & \multicolumn{4}{|c|}{ Microrregião de Campo Maior } & \multicolumn{3}{|c|}{ Microrregião de Teresina } & \multicolumn{3}{|c|}{ Microrregião Valença } & \multirow{2}{*}{$\begin{array}{l}\text { Total } \\
05\end{array}$} \\
\hline & \multicolumn{3}{|c|}{ Campo Maior } & \multirow{2}{*}{$\begin{array}{c}\text { Castelo } \\
\text { C. } \\
\text { Saco }^{1}\end{array}$} & Freitas & \multicolumn{2}{|c|}{ Beneditinos } & \multicolumn{3}{|c|}{ Elesbão Veloso } & \\
\hline Localidades & Correição & Passarela & $\begin{array}{c}\mathrm{St}^{\circ} \\
\text { Antônio }\end{array}$ & & Nazaré & Graciosa & $\begin{array}{c}\text { P. } \\
\text { Alegre }^{2}\end{array}$ & Angical & $\begin{array}{c}\text { B. } \\
\text { Curral }^{3}\end{array}$ & Campos & 10 \\
\hline Equinos & 08 & 23 & 22 & 06 & 27 & 01 & - & 18 & 11 & 13 & 129 \\
\hline Asininos & 15 & 47 & - & 01 & 05 & 03 & 03 & 36 & - & - & 110 \\
\hline Total & & 12 & & & & 39 & & & 78 & & 239 \\
\hline
\end{tabular}

Legenda: ${ }^{1}$ Canto do Saco, ${ }^{2}$ Porto Alegre, ${ }^{3}$ Baixa do Curral

Tabela 2- Número e espécies de carrapatos coletados de equinos e asininos por microrregião, município e localidade no estado do Piauí, nos meses de agosto dos anos de 2010 e 2011

\begin{tabular}{|c|c|c|c|c|c|c|c|c|}
\hline Microrregiões & \multicolumn{5}{|c|}{ Campo Maior } & \multicolumn{3}{c|}{ Teresina } \\
\hline Municípios & \multicolumn{3}{|c|}{ Campo Maior } & Castelo & $\begin{array}{c}\text { Jose de } \\
\text { Freitas }\end{array}$ & Beneditinos \\
\hline Localidades & Correição & Passarela & $\begin{array}{c}\text { Sto } \\
\text { Antônio }\end{array}$ & C. saco & Nazaré & Graciosa & P. Alegre \\
\hline D. nitens & - & 54 & - & 31 & 570 & 16 & 10 & 681 \\
\hline A. cajennense & - & - & - & - & 08 & - & - & 08 \\
\hline A. parvum & - & - & - & - & 03 & - & - & 03 \\
\hline Total & & -85 & & & & 607 & 692 \\
\hline
\end{tabular}

\subsection{IDENTIFICAÇÃO DOS CARRAPATOS}

Os carrapatos coletados e identificados por hospedeiro foram identificados morfologicamente segundo a chave taxonômica modificada de Aragão e Fonseca ${ }^{1}$ (ONOFRIO, 2006).

\footnotetext{
${ }^{1}$ ARAGÃO, H. B., FONSECA, F. Notas de ixodologia. Memorial do Instituto. Oswaldo Cruz, v. 59, p.119-129, 1961
} 


\subsection{EXTRAÇÕES DE DNA DOS CARRAPATOS}

Os carrapatos, após identificados morfologicamente foram submetidos à extração de DNA (Tabela 3) para pesquisa de Rickettsia, utilizando o Wizard® Genomic DNA Purification Kit (PROMEGA, USA), seguindo as instruções do fabricante.

Tabela 3 - Número e espécies de carrapatos coletados de equinos e asininos, nos quais foi realizada PCR para pesquisa de Rickettsia, por microrregião estudada

\begin{tabular}{lccccc}
\hline & \multicolumn{2}{c}{ Campo Maior } & \multicolumn{2}{c}{ Teresina } & Total \\
\cline { 2 - 6 } & Equinos & Asininos & Equinos & Asininos & \\
Dermacentor nitens & 31 & 31 & 31 & 12 & 105 \\
Amblyomma cajennense & - & - & 8 & - & 8 \\
Amblyomma parvum & - & - & 3 & - & 3 \\
Total & 31 & 31 & 42 & 12 & 116 \\
\hline
\end{tabular}

\subsection{REAÇÕES EM CADEIA PELA POLIMERASE (PCR)}

A presença de Rickettsia nos carrapatos foi avaliada através da amplificação de fragmentos do gene citrato sintase $(g / t A)$, presente em todas as espécies de rickettsias e os genes que codificam as proteínas externas de membrana (ompA $e$ ompB), utilizados para a confirmação da infecção por Rickettsia do GFM (Quadro 1). 
Quadro 1 - Lista dos primers utilizados nas reações da PCR para a identificação das rickettsias nos carrapatos - São Paulo - 2012

\begin{tabular}{|c|c|c|c|c|}
\hline $\begin{array}{l}\text { Gene alvo e } \\
\text { pares de } \\
\text { primers }\end{array}$ & $\begin{array}{l}\text { Especifici } \\
\text { dade }\end{array}$ & $\begin{array}{l}\text { Sequência dos primers } \\
\left(5^{\prime} \rightarrow 3^{\prime}\right)\end{array}$ & $\begin{array}{l}\text { Fragmento } \\
\text { amplificado } \\
\text { (pb) }\end{array}$ & Referência \\
\hline gltA & \multirow{3}{*}{$\begin{array}{l}\text { Gênero } \\
\text { Rickettsia }\end{array}$} & GCAAGTATCGGTGAGG & \multirow{3}{*}{401} & \multirow{3}{*}{ Labruna et al., 2004b } \\
\hline CS-78 & & ATGTAAT & & \\
\hline CS- 323 & & $\begin{array}{l}\text { GCTTCCTTAAAATTCAA } \\
\text { TAAATCAGGAT }\end{array}$ & & \\
\hline ompA & \multirow{3}{*}{$\begin{array}{l}\text { Grupo da } \\
\text { Febre } \\
\text { Maculosa }\end{array}$} & & \multirow{3}{*}{632} & \multirow{3}{*}{$\begin{array}{c}\text { Roux et al., 1996; Fournier } \\
\text { et al., 1998; Regnery et } \\
\text { al., } 1991\end{array}$} \\
\hline $\operatorname{Rr} 190.70$ & & 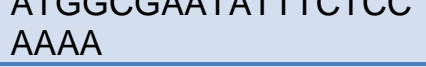 & & \\
\hline Rr 190.701 & & $\begin{array}{l}\text { GTTCCGTTAATGGCAG } \\
\text { CATCT }\end{array}$ & & \\
\hline$o m p B$ & \multirow{3}{*}{$\begin{array}{l}\text { Gênero } \\
\text { Rickettsia }\end{array}$} & CCGCAGGGTTGGTAAC & \multirow{3}{*}{820} & \multirow{3}{*}{ Roux; Raoult, 2000} \\
\hline 59 & & CCTAA & & \\
\hline 807 & & $\begin{array}{l}\text { CCTTTTAGATTACCGCC } \\
\text { TAA }\end{array}$ & & \\
\hline
\end{tabular}

\subsection{ANÁLISES DOS PRODUTOS AMPLIFICADOS}

Os produtos amplificados da reação de PCR foram visualizados com aparelho de eletroforese em gel de agarose a 2\% (100 ml TBE 0,5\%; 2,0g agarose UltraPure $^{\mathrm{TM}}$ Agarose Invitrogen $\left.{ }^{\mathrm{TM}}\right)$, em cuba horizontal e tampão TBE $0,5 \mathrm{X}(0,045 \mathrm{M}$ Tris-borato; $0,001 \mathrm{M}$ EDTA pH 8,0) submetida à voltagem de 1 a $10 \mathrm{~V} / \mathrm{cm}$ durante 30 minutos. A revelação foi feita em solução de brometo de etídeo $(0,5 \mathrm{ug} / \mathrm{ml}) \mathrm{em}$ agitação por 15 a 30 minutos e a visualização das bandas em transiluminador ultravioleta.

\subsection{PURIFICAÇÃO E SEQUENCIAMENTO DE NUCLEOTIDEOS}

Os produtos da PCR foram purificados utilizando o kit comercial ExoSAP-IT (USB Corporation, EUA), que consiste em Exonuclease I (Exo I) para digerir excesso de primers e Shrimp Alkaline Phosphatase (SAP) para degradar excesso de nucleotídeos provenientes da PCR. Para tal, em microtubo identificado colocou-se 3 $\mu \mathrm{L}$ de ExoSAP e adicionou-se 7,5 $\mu \mathrm{L}$ da amostra amplificada na PCR, em seguida 
as amostras foram colocadas no termociclador nas temperaturas de $37^{\circ} \mathrm{C}$ por 15 minutos e $80^{\circ} \mathrm{C}$ por mais 15 minutos.

Após a purificação os nucleotídeos estavam prontos para serem utilizados na reação de sequenciamento com o kit comercial BigDye TM Terminator (Perkin Elmer, EUA) de acordo com especificações do fabricante: $5 \mu \mathrm{L}$ de DNA purificado concentração máxima de $100 \mathrm{ng}, 1 \mu \mathrm{L}$ de água MilliQ, $1 \mu \mathrm{L}$ de "Big Dye", $1 \mu \mathrm{L}$ de oligonucleotídeos iniciadores específicos senso e anti-senso (5 pmoles/ $\mu \mathrm{L})$, e $2 \mu \mathrm{L}$ de buffer. As amostras foram sequenciadas em sequenciador automático modelo ABI 377 (Applyed Biosystem, Foster, CA), disponível no VPS/FMVZ/USP de acordo com as instruções do fabricante.

\subsection{REAÇÃO DE IMUNOFLUORESCÊNCIA INDIRETA (RIFI)}

Os soros foram testados pela RIFI frente aos antígenos $R$. rickettsii cepa Taiaçu (PINTER; LABRUNA 2006), $R$. parkeri cepa At24 (SILVEIRA et al., 2007), $R$. amblyommii cepa Ac37 (LABRUNA et al., 2004), R. rhipicephali cepa HJ5 (LABRUNA et al., 2005) e $R$. bellii cepa Mogi (PINTER; LABRUNA 2006). Esta sorologia foi realizada segundo o protocolo de Horta et al. (2004) utilizando anti-lgG de equino (Sigma Diagnostics, St Louis). Em cada lâmina, soros conhecidamente negativos e positivos foram utilizados como controles. Os soros reativos na diluição 1:64 para qualquer espécie de rickettsia foram testados em diluições seriadas na base dois, para determinação do título da reação. Os soros que demonstraram, para uma determinada espécie de rickettsia, titulação quatro vezes maior que para as demais espécies testadas, foram considerados homólogos para a primeira espécie de rickettsia, conforme padrões previamente definidos (HORTA et al., 2004).

\subsection{ANÁLISE ESTATÍSTICA}

Os resultados observados na RIFI foram analisados através de tabelas de contingências com as diferentes variáveis. As comparações dos dados para 
observação de possíveis associações entre os resultados da RIFI e destes com os fatores de risco analisados, foram feitas pelo teste Qui-Quadrado e cálculo dos "Odds Ratio" para cada variável. Para os testes estatísticos foi utilizado o programa computacional spss 20.

Um questionário aplicado em cada localidade, onde foram realizadas coletas, permitiu avaliar alguns possíveis fatores de risco para os animais e as rickettsioses, dentre eles: acesso a mata, acesso a piquetes com vegetação nativa e permanecer estabulados.

Outros possíveis fatores de associação contidos no questionário foram excluídos, devido a homogeneidade ou grande divergência das informações, que inviabilizariam uma análise associativa tais como: Todos os animais eram de zona rural, de áreas não endêmicas, os humanos que mantinham contato com os animais já haviam sido picados por carrapatos além de clima, vegetação e pluviosidade bastante semelhantes.

Comparações entre a ocorrência de anticorpos anti-Rickettsia spp e as regiões estudadas foram feitas através do teste do Qui-quadrado. 


\section{RESULTADOS E DISCUSSÃO}

Os resultados são apresentados seguidos da discussão.

\subsection{PCR DOS CARRAPATOS}

Foram analisados individualmente 116 carrapatos pela técnica de PCR (tabela 3). Duas amostras de DNA, extraídas de carrapatos adultos da espécie $A$. parvum (coletados de cavalos no Haras Nazaré), tiveram produtos amplificados para o gene gltA, que identifica o gênero Rickettsia. Destas duas, apenas uma, foi positiva para amplificação a partir da PCR, para os genes ompA e ompB que identificam Rickettsia do GFM .

Apesar dos equinos serem os hospedeiros primários do $A$. cajennense, poucos desses vetores foram observados parasitando os equídeos estudados. Estes carrapatos foram encontrados apenas no Haras Nazaré, na microrregião de Teresina (Tabela 2) e somente parasitando equinos. Em relação à espécie D.nitens, observou-se parasitismo na grande maioria dos equinos e inclusive nos asininos (Tabela 2). Do total de oito $A$. cajennense coletados e analisados pela PCR, nenhum deles foi positivo para Rickettsia. $O$ mesmo resultado aplica-se às análises de PCR, realizadas nos carrapatos da espécie D.nitens utilizados.

\subsection{ANÁLISES DO SEQUENCIAMENTO GENÉTICO DAS AMOSTRAS POSITIVAS}

Foi verificado através de técnicas moleculares em carrapatos Ixodídeos da espécie A. parvum, a infecção por uma provável nova Rickettsia do GFM, que no presente estudo será referida como "Candidatus Rickettsia andeanae" cepa Piauí. Esta Rickettsia apresentou $100 \%$ de identidade genética com a "Candidatus Rickettsia andeanae" encontrada no Peru em carrapatos A. maculatum e Ixodes 
boliviensis (BLAIR et al., 2004) e Rickettsia sp. cepa Argentina, encontrada na Argentina em carrapatos $A$. parvum e Amblyomma pseudoconcolor (PACHECO et al., 2007; TOMASSONE et al., 2010).

Para melhor entendimento da relação desta Rickettsia, encontrada no presente estudo, e as demais rickettsias do GFM já descritas, foi realizado o sequenciamento e a análise genética das duas amostras, para os genes gltA, ompA e ompB.

O padrão de segregação da amostra brasileira foi concordante para os genes estudados, apontando-se identidade genica (100\%) em relação à amostra Rickettsia sp. cepa Argentina (PACHECO et al., 2007) e para a amostra "Candidatus Rickettsia andeanae" (BLAIR et al., 2004; JIANG et al., 2005). Esta última apresentou padrão similar as amostras brasileira e argentina para os genes gltA (100\%) e ompB (100\%). Não foi possível realizar a análise do gene ompA, devido ao fato de que a sequência depositada no GenBank referentes ao gene ompA da amostra "Candidatus Rickettsia andeanae" não ser homóloga à encontrada neste trabalho.

Considerando-se a análise de distância para o gene glt $A$, verificou-se a formação de um grande cluster politômico, o que é esperado, uma vez que trata-se de um gene altamente conservado entre as espécies de Rickettsia.

A proximidade gênica entre as amostras "Candidatus Rickettsia andeanae cepa Piauí” e Rickettsia sp. cepa Argentina e “Candidatus Rickettsia andeanae”, está suportada por elevados valores de bootstrap para o gene codificador ompB (96), concordando com as elevadas identidades verificadas (100\%).

$\mathrm{Na}$ análise de identidade genética, empregando-se a sequência do gene gltA obtida no presente estudo, com relação à sequências obtidas no GeneBank, podese verificar que a amostra brasileira aqui estudada é 100\% idêntica as amostras "Rickettsia sp. cepa Argentina" (GenBank-EF451001.1) e "Candidatus Rickettsia andeanae" cepa T163 (GenBank-GU169051.1). As menores identidades verificadas entre a amostra brasileira e as amostras incluídas na análise ocorreram com relação às amostras de $R$. coronii cepa Malish7 e R. prowazekii cepa Madri E (Figura 3), com identidades de $41,9 \%$ e $42,9 \%$, respectivamente.

Para o gene ompB a amostra "Candidatus Rickettsia andeanae" cepa Piauí" tambem foi $100 \%$ identica a amostra Rickettsia sp. cepa Argentina (GenBankEF451003.1) (PACHECO et al., 2007) e "Candidatus Rickettsia andeanae" 
(GenBank-GU395297) (JIANG et al., 2005). A menor identidade encontrada foi com relação a amostra Rickettsia prowazekii 79,2\% (Figura 4).

Este é o primeiro relato da presença de "Candidatus Rickettsia andeanae" cepa Piauí no Brasil.

Figura 3 - Árvore de distancia obtida pelo algoritmo de Neighbor-Joining para o gene gltA, modelo evolutivo MCL. Contendo amostras obtidas no GeneBank e a amostra obtida no presente trabalho("Candidatus Rickettsia andeanae" cepa Piauí «). Os números localizados sobre cada nó representam os valores de bootstrap, estando demonstrados valores superiores a 20

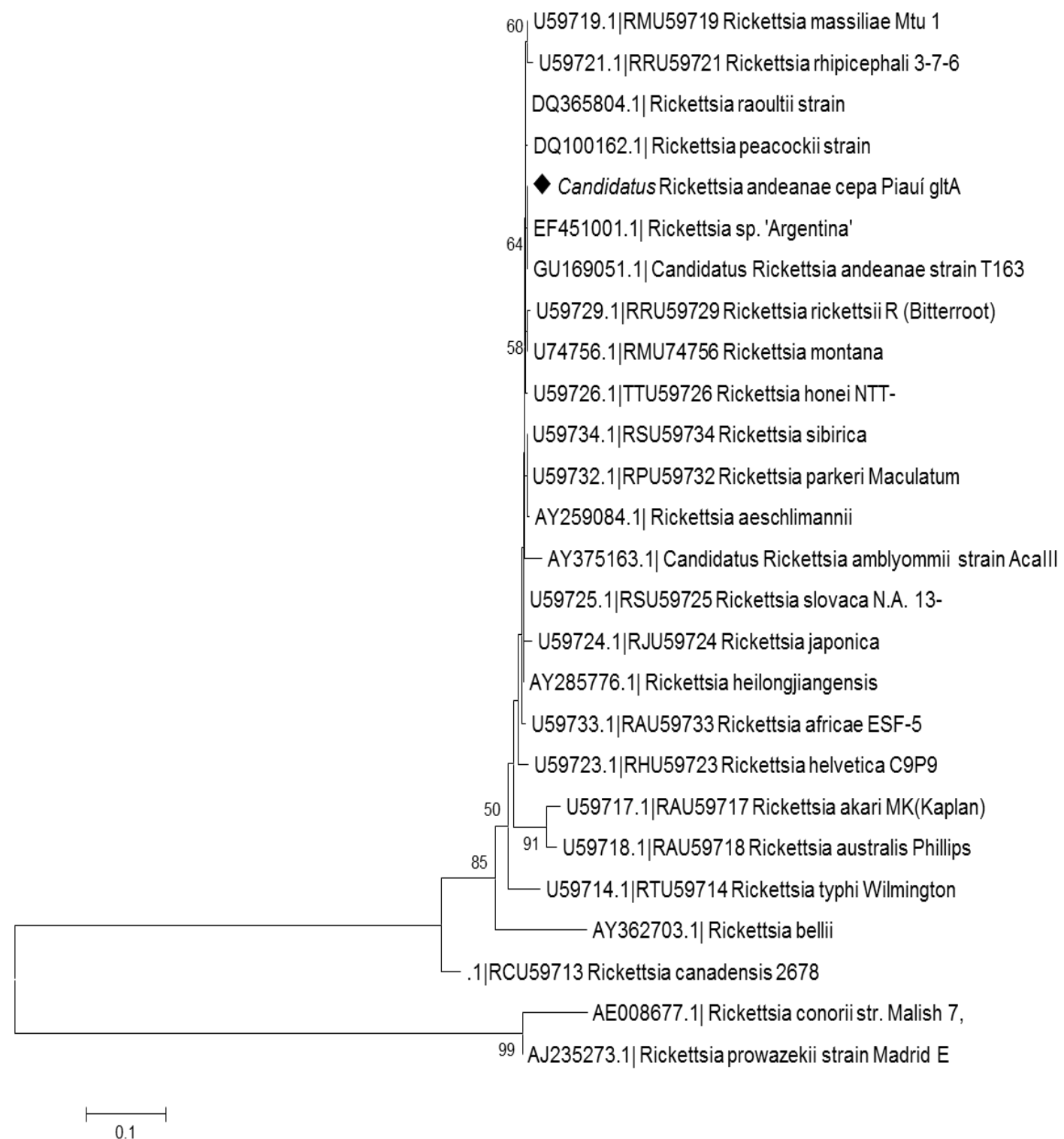


Figura 4 - Árvore de distância obtida pelo algoritmo de Neighbor-Joining para o gene ompB, modelo evolutivo MCL., contendo amostras obtidas no GeneBank e a amostra obtida no presente trabalho (Candidatus Rickettsia andeanae cepa Piauí ४). Os números localizados sobre cada nó representam os valores de bootstrap, estando demonstrados valores superiores a 20

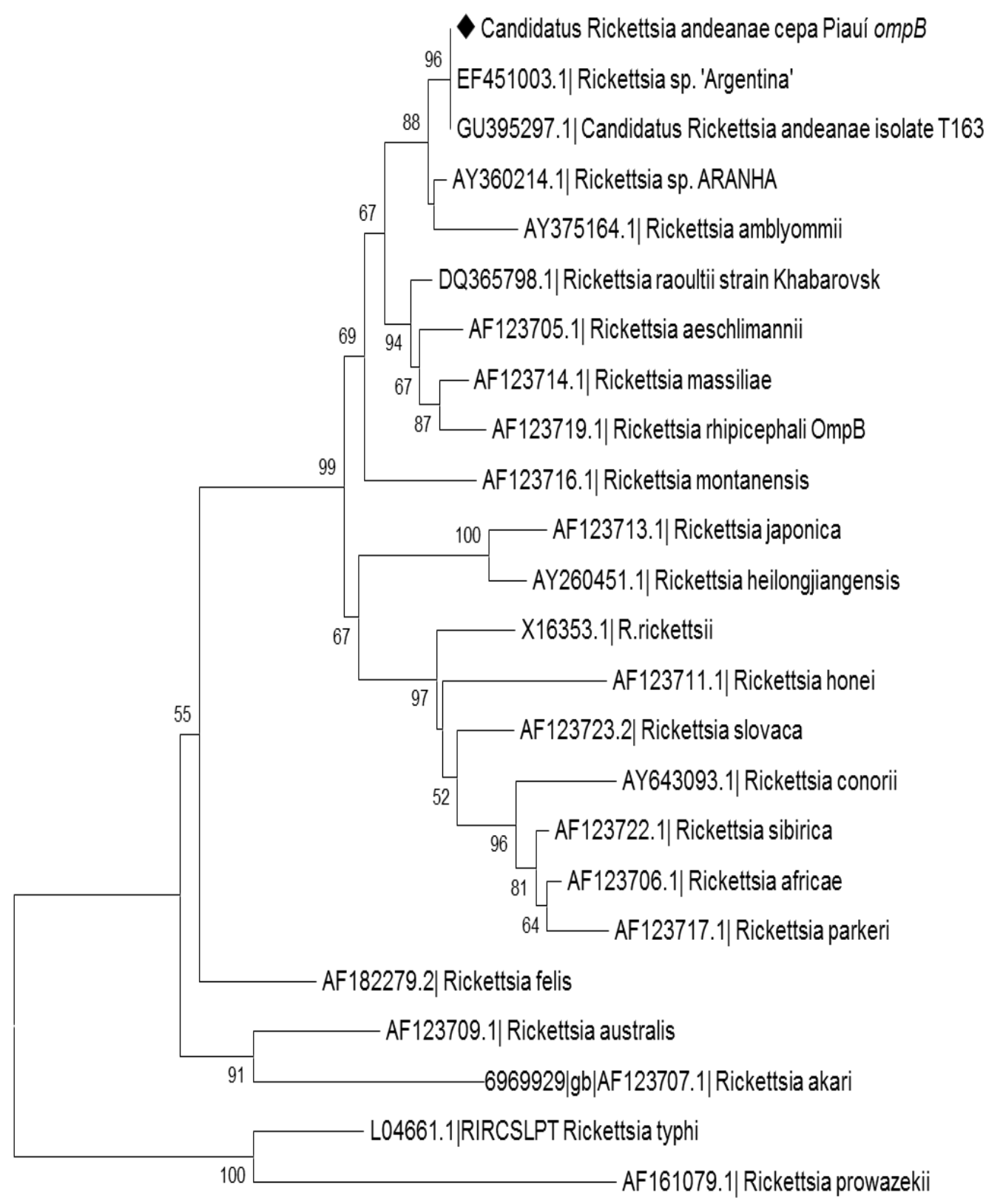




\subsection{REAÇÃO DE IMUNOFLUORESCÊNCIA INDIRETA}

A frequência de positividade na RIFI, para os equídeos (equinos e asininos) para pelo menos um dos antígenos de Rickettsias testados ( $R$. rickettsii, $R$. parkeri, $R$. amblyommii, $R$. rhipicephali e $R$. bellii), foi de 52,3\% (125/239). Da mesma forma, separadamente para cada antígeno de Rickettsia testado, observou-se presença de anticorpos em: 43,9\% (105/239) para $R$. amblyommii, 13,4\%( 32/239) para $R$. parkeri, 21,3\%( 51/239) para $R$. rickettsii, 36\% ( 86/239) para $R$. rhipicephali e $26,8 \%$ (64/239) para R. bellii.

A tabela 4 apresenta os resultados de ocorrência de anticorpos antiRickettsia spp por micro região estudada.

Tabela 4 - Ocorrência (\%) de anticorpos anti-Rickettsia spp nos equídeos por microrregião estudada no estado do Piauí

\begin{tabular}{lccc}
\hline & \multicolumn{3}{c}{ Microrregião } \\
\cline { 2 - 4 } & Campo Maior & Teresina & Valença \\
\hline Animais amostrados & 122 & 39 & 78 \\
\hline Animais positivos & 51 & 17 & 57 \\
\hline$\%$ de positivos & $41,8^{\mathrm{a}}$ & $43,6^{\mathrm{a}}$ & $73,1^{\mathrm{b}}$ \\
\hline
\end{tabular}

Letras diferentes na mesma linha $p<0,001$

A ocorrência de animais soropositivos em Valença foi significativamente maior do que nas outras duas microrregiões $(p<0,001)$. É importante observar que este resultado reflete a presença de anticorpos para pelo menos uma das rickettsias analisadas. Nessa microrregião quando da visita do grupo, não foi possível encontrar nenhum carrapato nos animais, entretanto estes resultados indicam que estes ácaros já haviam infestado os equídeos e transmitido a bactéria, sendo importante visitas futuras na tentativa de se encontrar os vetores e inclusive alguma Rickettsia nesses carrapatos.

Considerando equinos e asininos separadamente, a frequência de positividade na RIFI, para antígenos de pelo menos uma das rickettsias estudadas, foi de $39,5 \%$ (51/129) para equinos e $67,3 \%$ (74/110) para asininos. A tabela 5 
mostra a frequência de positividade geral, dos asininos e equinos, para cada uma das espécies de Rickettsia estudadas neste trabalho.

Tabela 5 - Percentual de positividade e número de positivos na RIFI de equinos ( $n=129)$ e asininos $(n=110)$ para as espécies de Rickettsia estudadas

\begin{tabular}{|l|c|c|c|c|c}
\hline & R. amblyommii & R. riphicephali & R. rickettsii & R. parkeri & R. bellit \\
\hline Asininos & $54,5(60)$ & $46,4(51)$ & $26,4(29)$ & $22,7(25)$ & $42,7(47)$ \\
\hline Equinos & $34,9(45)$ & $27,1(31)$ & $17,1(22)$ & $05,4(07)$ & $13,2(17)$ \\
\hline
\end{tabular}

Neste estudo, as áreas em questão, não são consideradas endêmicas e nem há estudos anteriores sobre a presença de infecção por Rickettsia em humanos, equinos e asininos ou outros vertebrados.

Comumente, não se observam manifestações clínicas em infecções por Rickettsia em equinos (HAYDON et al., 2008), assim os equinos estudados neste trabalho também não apresentavam nenhum sinal clínico detectável, típicos de rickettsioses.

A RIFI é considerada uma técnica padrão para o diagnóstico sorológico de infecções por Rickettsia, embora possa apresentar algumas reações cruzadas e esteja sujeita a subjetividade do técnico. Porém, altos títulos de anticorpos são normalmente um forte indicativo de infecção específica (VIANNA et al., 2008).

Horta et al. (2004), estudando soroprevalência em áreas endêmicas de febre maculosa no estado de São Paulo, reportaram equinos reagentes a antígenos de $R$. rickettsii com valor de $77 \%$ (17/22) e títulos variando de 64 a 4,096, porem não verificou-se reatividade na RIFI para asininos. Sangioni et al. (2005) relataram em equinos, sorologia de RIFI para anticorpos anti- $R$. rickettsii, variando de $57,1 \%$ a 90\% em fazendas de áreas endêmicas e negatividade nas áreas não endêmicas do estado de São Paulo. Em outro estudo em área endêmica (Pedreira- SP) 77,8 \% (7/9) dos equinos foram positivos na RIFI para antígenos de R. rickettsii, com títulos maiores que 1024 (LEMOS et al.,1996). Vianna et al. (2008), estudando sorologia em equídeos na Vila do Capoeirão, Itabira (MG), obtiveram 100\% (11/11) de positividade por meio da RIFI para anticorpos anti- Rickettsia rickettisii em equinos e $100 \%$ (3/3) para asininos. Estudos recentes em Juiz de Fora (MG), região endêmica 
para FMB, demonstraram sorologia de RIFI positivas para equinos em 41,0\% (16/39) das amostras, para antigenos de $R$. rickettsii (PACHECO et al., 2011). Assim como o observado neste trabalho, em todos os estudos descritos os autores também não encontraram carrapatos da especie $A$. cajennense infectados por Rickettsia.

No presente trabalho, embora equinos e asininos tenham apresentado resultados positivos na RIFI para antígenos de $R$. rickettsii, respectivamente $17,1 \%$ e $26,4 \%$, a soropositividade e titulações foram inferiores aos observados pelos autores que também pesquisaram anticorpos em equídeos no Brasil (HORTA et al., 2004; LEMOS et al.,1996; VIANNA et al., 2008; PACHECO et al., 2011) O gráfico 1, mostra a relação dos títulos apresentados pelos equídeos, analisados pela RIFI para R. rickettsii. A baixa positividade e intensidade de títulos podem estar relacionados ao fato deste estudo ter sido realizado em região não endêmicas para FMB.

Os resultados deste trabalho corroboram com os encontrados por MoraesFilho et al. (2009), que investigaram a presença de $R$. rickettsii em equinos encaminhados ao Centro de Controle de Zoonose do Município de São Paulo (CCZ/SP). Os autores observaram pela RIFI 17,6\% de ocorrência para equinos, avaliados contra antígenos de $R$. rickettsii, dado bastante semelhante aos encontrados no presente estudo.

A procedência dos equinos e a espécie de carrapato presente na região são fatores importantes a serem considerados. No trabalho de Moraes-Filho et al. (2009), os animais eram errantes e viviam em zona urbana (São Paulo), em áreas onde o carrapato mais frequente é $A$. aureolatum, que tem cães como hospedeiros primários. Por outro lado, no presente estudo os animais eram da zona rural, onde $D$. nitens, $A$. cajennense e $A$ parvum foram às espécies encontradas parasitando os equídeos analisados. Contudo maiores estudos seriam necessários para identificar outras espécies de carrapatos ocorrentes na região, pois as coletas foram feitas em uma única época do ano e somente foram obtidas formas de vida parasitária dos carrapatos.

Toledo et al. (2009), em estudos com equinos em Londrina no Paraná, em área não endêmica para $\mathrm{FMB}$, observaram 38,5\% de soropositividade para antígenos de $R$. rickettsii e $11,5 \%$ para antígenos de $R$. parkeri. Resultados pouco menores que os encontrados em áreas endêmicas, porem duas vezes maiores que os observados neste estudo (17,1\% para $R$. rickettsii e $5,4 \%$ para $R$. parkeri). Contudo os títulos observados por estes autores para essas rickettsias, semelhante 
ao observado no presente estudo, não passaram de 512 para estas rickettsias. É importante salientar que os equinos de Londrina, eram de área urbana (animais de carroceiros), enquanto que neste estudo os animais eram de áreas rurais. No estudo feito em Londrina, Toledo et al. (2009) também pesquisaram Rickettsia em D. nitens e A. cajennense e como o observado no presente estudo, nenhum ácaro foi positivo nas análises moleculares.

Em Almirante Tamandaré (PR), região não endemica para rickettsioses, outro estudo envolvendo cavalos, demonstrou reação sorologica de RIFI positiva para $R$. rickettsii em $8,45 \%$ dos equinos (6/71) (BATISTA et al., 2010). Tamekuni et al. (2010) em estudo, com equinos e sorologia para $R$. rickettsii e $R$. parkeri, realizado em seis haras no Paraná, observaram resultados de frequência de soropositiva de 5,5\% (15/273) para $R$. rickettsii e 1,3\% (5/273) para R. parkeri, e títulos de anticorpos inferiores aos encontrados neste trabalho. Os resultados dos estudos do Paraná como os deste trabalho, no Piauí, apresentaram várias semelhanças provavelmente por ambos terem sido conduzidos em zonas não endêmicas para FMB.

É observada uma correlação entre áreas endêmicas para $R$. rickettsii e alta soropositividade nos equinos dessas regiões, ratificando esses animais como sentinelas para FMB. É valido ressaltar, que a maioria dos trabalhos com equídeos, em áreas endêmicas ou não, realizaram sorologia apenas para $R$. rickettsii e $R$. parkeri. Isto faz sentido, partindo do princípio de que estas rickettsias são as consideradas patogênicas e estão em circulação dentro do território nacional (Sudeste). Porém faz-se necessários mais estudos, avaliando também a presença de anticorpos contra outras espécies de rickettsias encontradas no país, uma vez que há grande possibilidade de reações cruzadas, e a presença e patogenicidade de outras espécies de rickettsias do GFM ainda são incertas ou necessitam de maiores estudos.

Os poucos trabalhos que mostram sorologia para rickettsias em asininos, tem mostrado resultados negativos ou baixos quando comparados aos de equinos (HORTA et al., 2004; VIANNA et al., 2008).Contudo, neste trabalho, considerando-se positividade para pelo menos uma das cinco rickettsias testadas, a frequência de asininos positivos foi maior que a frequência de equinos positivos nas regiões estudadas $(p<0,001)$. Esta associação pode estar relacionada ao fato de todos os asininos, exceto os aprendidos pela Correição da ADAPI, não estarem estabulados e terem acesso à mata, o que mostrou-se fator de risco no presente estudo. Este 
resultado mostra que os asininos não devem ser excluídos em estudos epidemiológicos de rickettsioses e devem ser também estudados como possíveis sentinelas para surtos de FMB, principalmente em áreas onde não há controle da população destes animais.

A frequência de reações cruzadas (Tabela 4) na RIFI para todas as espécies de Rickettsia testadas foi observada tanto para os equinos como para os asininos. Os títulos apresentaram variação 64 a 2024 e em ordem decrescente de positividade encontram-se: $R$. amblyommii $>R$. rhipicephali $>R$. bellii > R. rickettsii > R. parkeri. As relações entre os títulos de anticorpos e os antígenos utilizados na RIFI podem ser conferidas nos gráficos 1, 2, 3, 4 e 5.

Gráfico1 - Relação entre o número de animais analisados pela RIFI e os variações de títulos observados para antígenos de $R$. rickettsii

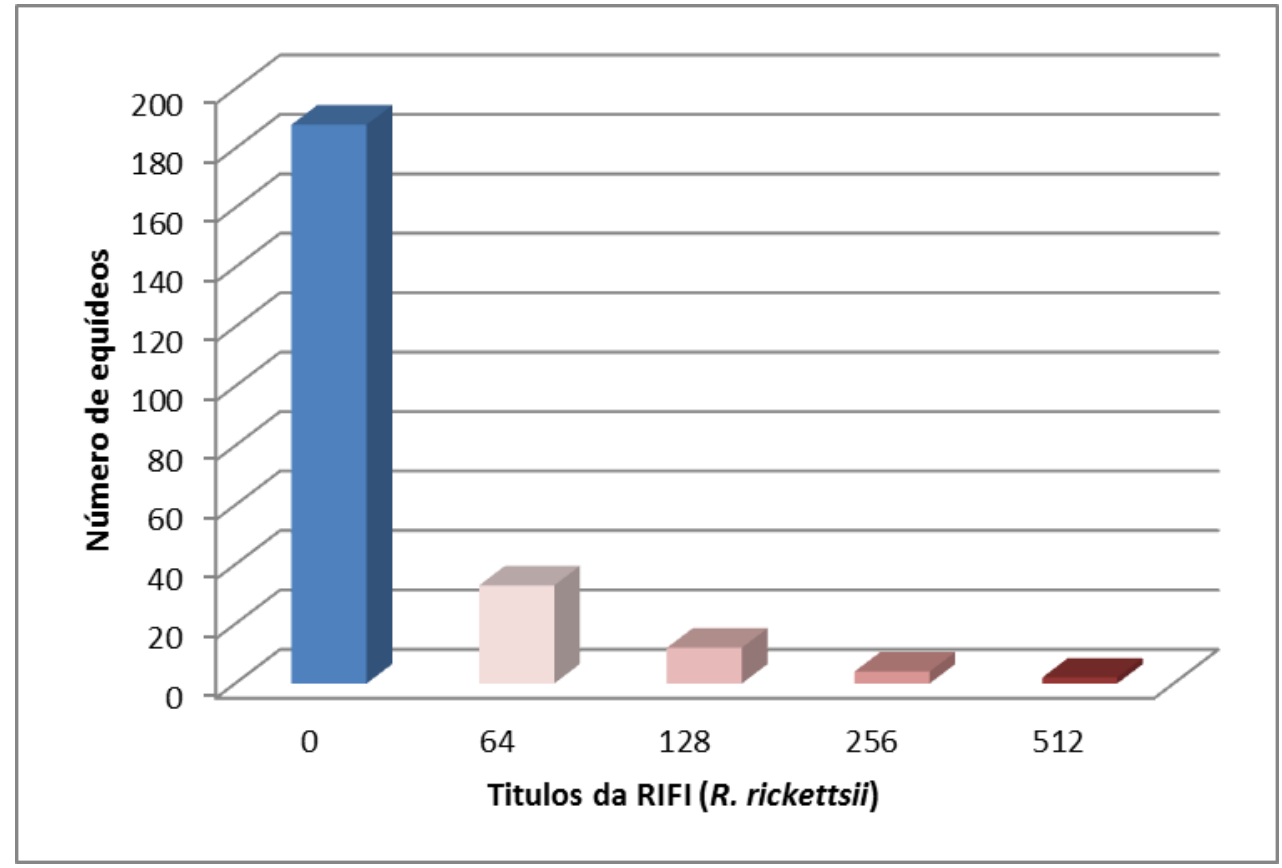


Gráfico 2 - Relação entre o número de animais analisados pela RIFI e os variações de títulosobservados para antígenos de R. amblyommii

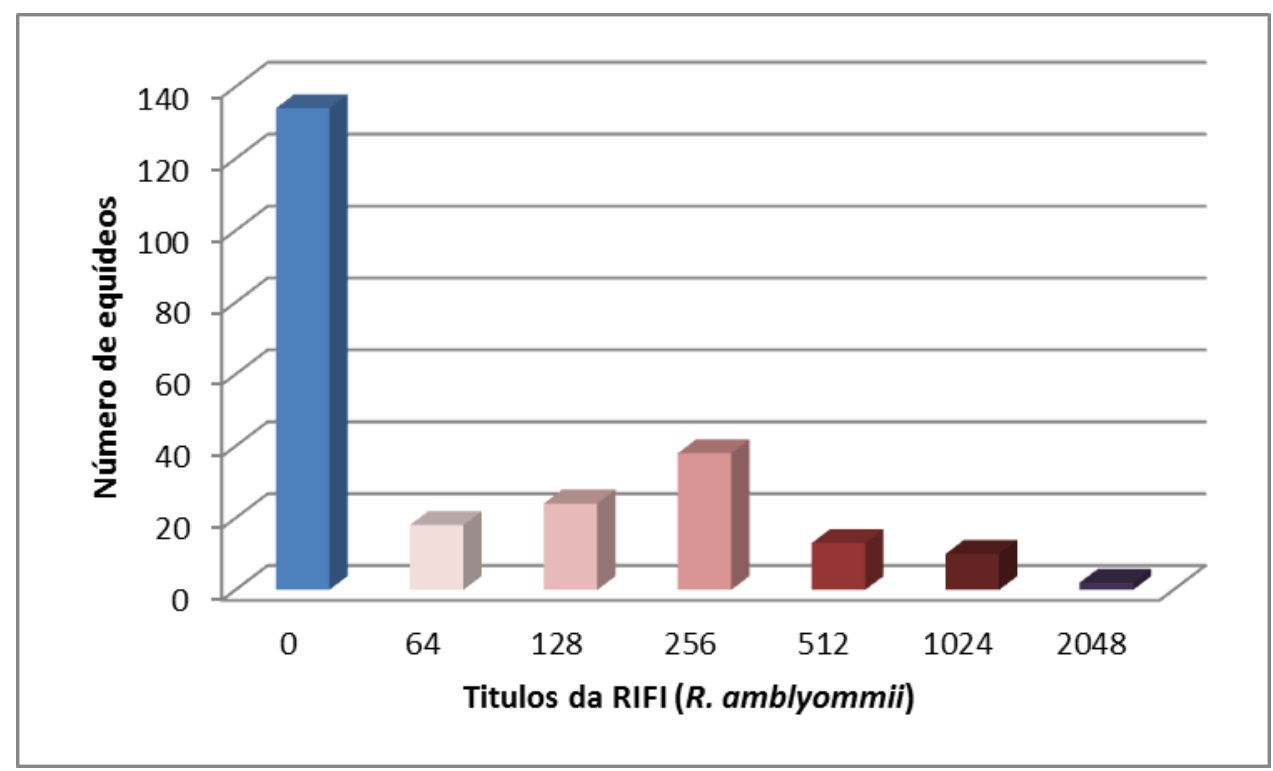

Gráfico 3 - Relação entre o número de animais analisados pela RIFI e os variações de títulos observados para antígenos de $R$. rhipicephali

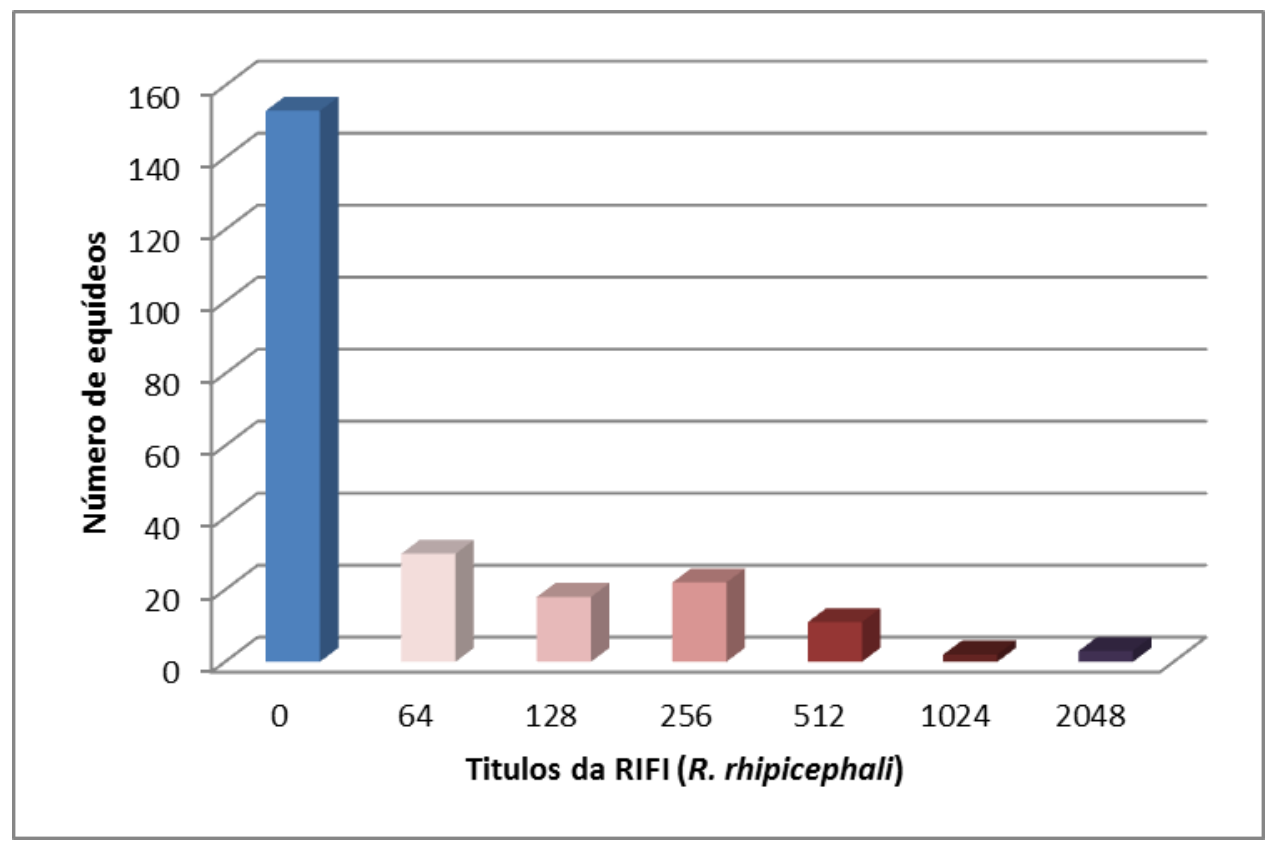


Gráfico 4 - Relação entre o número de animais analisados pela RIFI e os variações de títulos observados para antígenos de R. parkeri

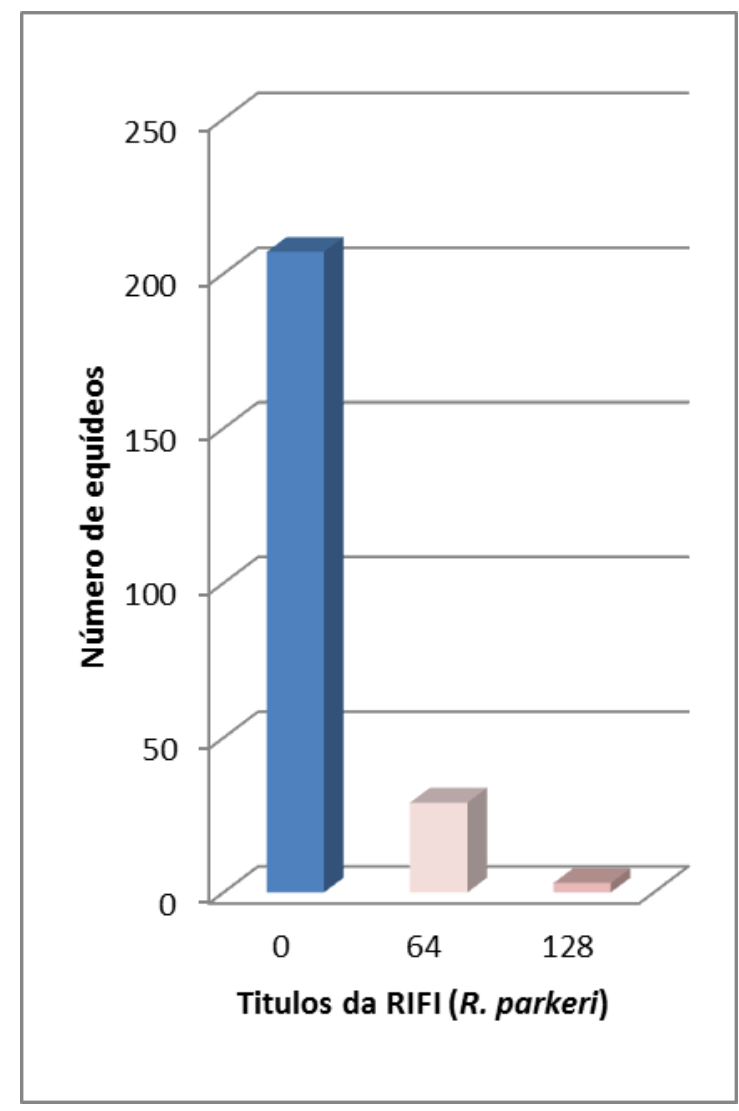

Gráfico 5 - Relação entre o número de animais analisados pela RIFI e os variações de títulos observados para antígenos de $R$. bellii

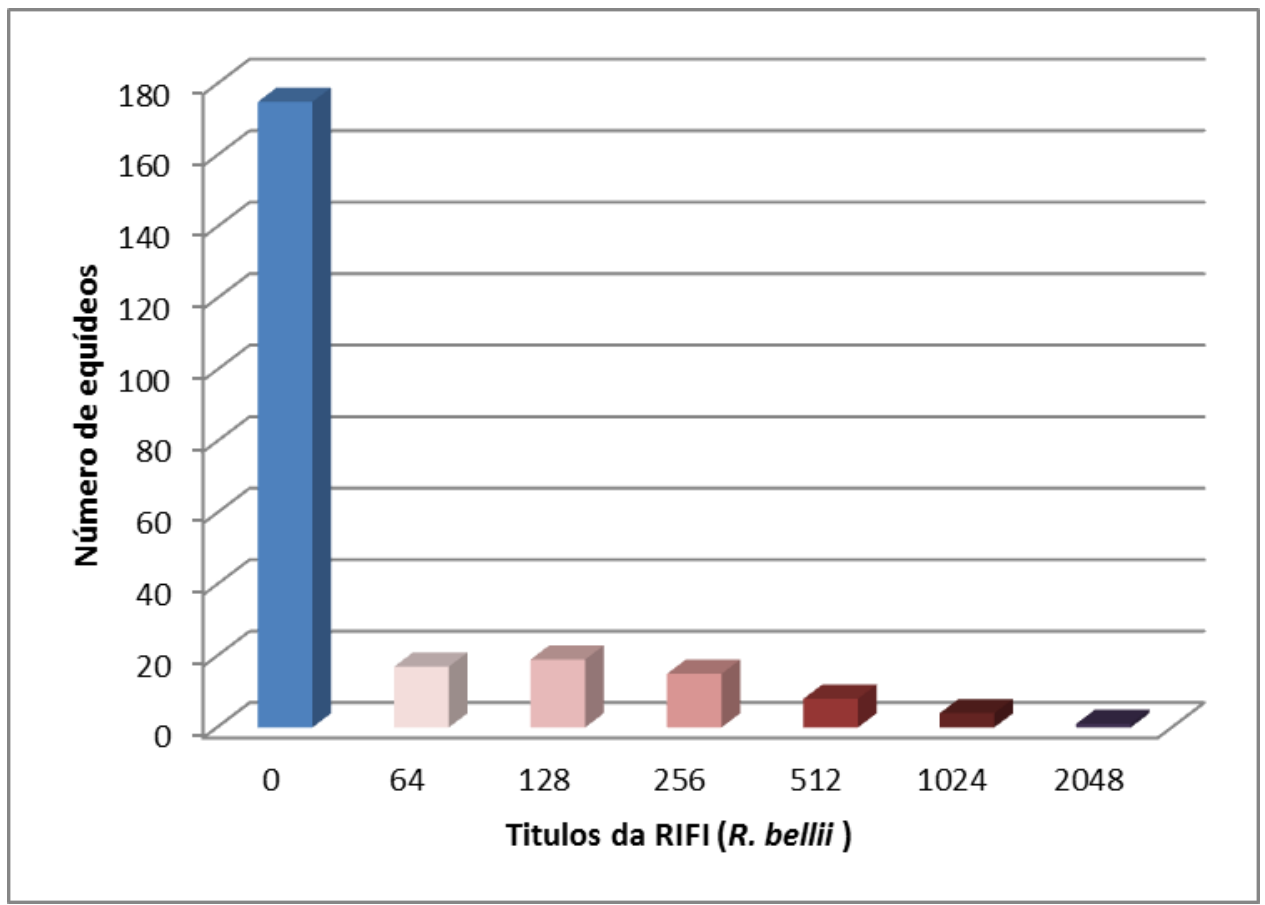


Nos casos em que um animal reagiu a mais de uma das rickettsias testadas na RIFI (reação cruzada), caso a diferença entre os maiores títulos fosse de pelo menos quatro vezes, considerou-se que o animal se infectou pela espécie de rickettsia responsável pelo maior título. Da mesma forma, caso um animal apresentasse título final de 128 para uma Rickettsia e negativo para os demais, considerou-se que o animal fora infectado pela primeira Rickettsia, uma vez que subentende-se que reações negativas na diluição inicial de 1:64 seriam virtualmente positivas ao título máximo de 32; desta forma, a diferença de 128 para 32 é de quatro vezes. (HORTA et al., 2004; LABRUNA et al.,2007).

A tabela 6 resume os prováveis agentes infecciosos que circulam em cada mesorregião estudada. $R$. amblyommii seguida de $R$. bellii e $R$. rhipicephali poderiam ser consideradas como espécies de Rickettsia circulantes nas áreas estudadas. Contudo os achados das análises moleculares, demonstram proximidades genéticas significativas entre "Candidatus Rickettsia andeanae" cepa Piauí, encontrada em carrapatos $A$. parvum que parasitavam cavalos nas regiões estudadas e $R$. amblyommii seguida de $R$. rhipicephali, de modo especialmente evidente na análise do gene ompB (Figura 5). Estas proximidades genéticas podem ser associadas com os altos títulos encontrados para estes antígenos e as reações cruzadas, que foram observadas na RIFI. Considerando estes fatos, "Candidatus Rickettsia andeanae" cepa Piauí e ou R. amblyommii, seria juntamente com $R$. bellii, os prováveis agentes circulantes na região estudada, causando a resposta imune observada pelo encontro de anticorpos no soro desses animais pela RIFI (Tabela 7). Estas inferências são reforçadas estatisticamente, com associação entre a positividade sorológica entre as diferentes espécies de Rickettsia testadas $(p<0,001)$.

Tabela 6 - Prováveis antígenos homólogos de Rickettsia utilizados na RIFI e relação de títulos por mesorregião e espécie de equídeos estudadas.

\begin{tabular}{|c|c|c|c|c|c|c|c|}
\hline & \multicolumn{2}{|c|}{ Campo Maior } & \multicolumn{2}{|c|}{ Teresina } & \multicolumn{2}{|c|}{ Valença } & \multirow[t]{2}{*}{ Total } \\
\hline & Equino & Asinino & Equino & Asinino & Equino & Asinino & \\
\hline R. amblyomii & 0 & 7 & 1 & 1 & 5 & 14 & 28 \\
\hline R. rhipicephali & 0 & 1 & 3 & 1 & 1 & 1 & 07 \\
\hline R. bellit & 07 & 11 & 0 & 0 & 1 & 6 & 25 \\
\hline Total ${ }^{1}$ & 07 & 19 & 04 & 02 & 07 & 21 & $60^{1}$ \\
\hline Total $^{2}$ & \multicolumn{2}{|c|}{26} & \multicolumn{2}{|c|}{06} & \multicolumn{2}{|c|}{28} & $60^{2}$ \\
\hline
\end{tabular}


Tabela 7- Variação dos títulos de anticorpos para as várias espécies de Rickettsias testadas pela RIFI e prováveis antígenos homólogos por asinino e equinos positivos e localidade de origem

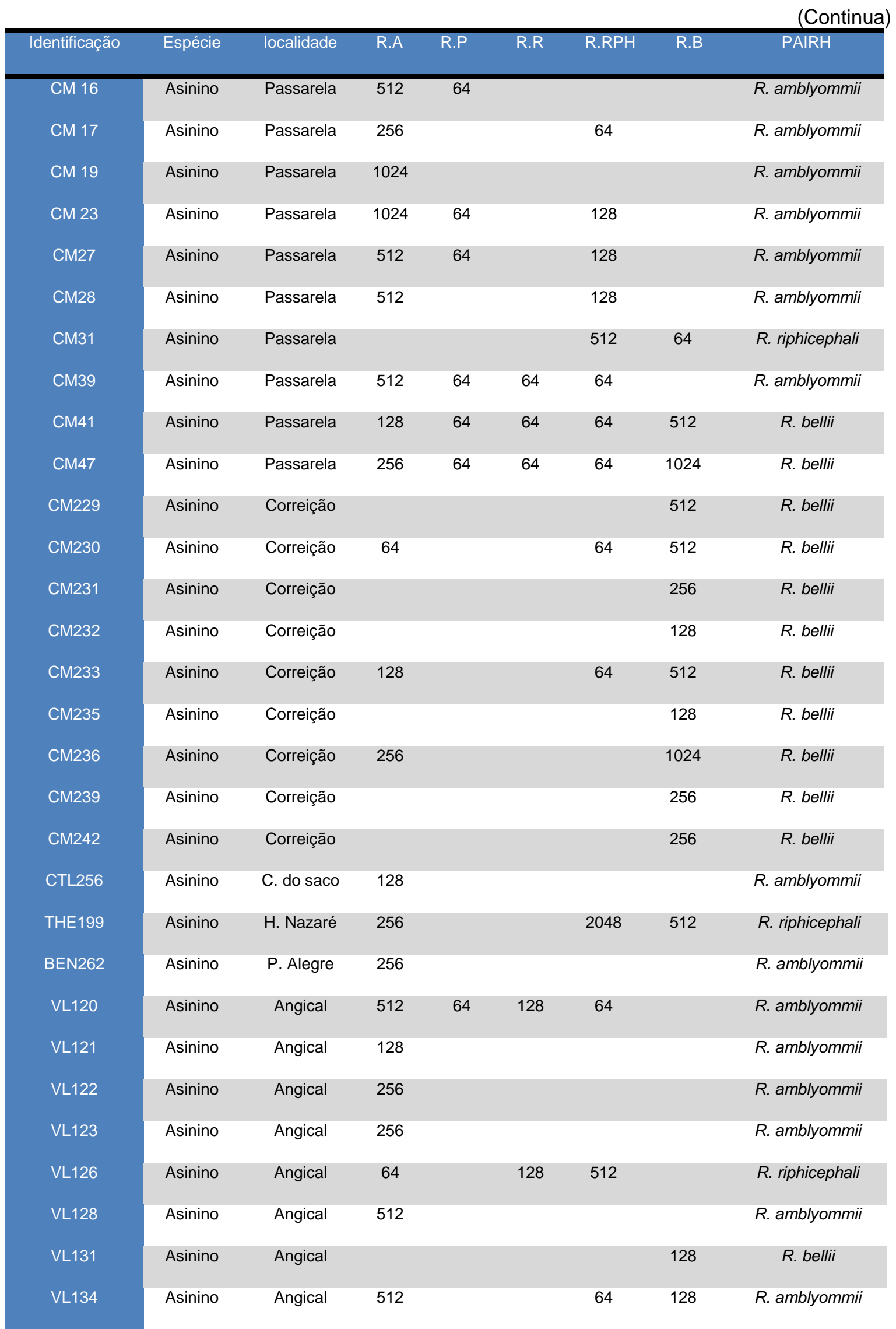




\begin{tabular}{|c|c|c|c|c|c|c|c|c|}
\hline & & & & & & & & (Conclusão) \\
\hline Identificação & Espécie & localidade & R.A & R.P & R.R & R.RPH & R.B & PAIRH \\
\hline VL135 & Asinino & Angical & 1024 & & & 64 & 128 & R. amblyommii \\
\hline VL140 & Asinino & Angical & 256 & & & & 64 & R. amblyommii \\
\hline VL142 & Asinino & Angical & & & & & 128 & R. bellii \\
\hline VL143 & Asinino & Angical & 2048 & 64 & 64 & 512 & 512 & R. amblyommii \\
\hline VL144 & Asinino & Angical & 1024 & & & 256 & 64 & R. amblyommii \\
\hline VL146 & Asinino & Angical & & & & & 128 & R. bellii \\
\hline VL147 & Asinino & Angical & 1024 & 64 & 64 & 256 & 128 & R. amblyommii \\
\hline VL148 & Asinino & Angical & & & & & 256 & R. bellii \\
\hline VL150 & Asinino & Angical & 1024 & & & 64 & 256 & R. amblyommii \\
\hline VL154 & Asinino & Angical & 256 & & & 64 & 64 & R. amblyommii \\
\hline VL149 & Asinino & Angical & & & & & 128 & R. bellii \\
\hline CM48 & Equino & Passarela & & & & & 2048 & R. bellii \\
\hline CM49 & Equino & Passarela & & & & & 1024 & R. bellii \\
\hline CM54 & Equino & Passarela & 64 & & & & 512 & R. bellii \\
\hline CM55 & Equino & Passarela & 64 & & & & 256 & R. bellii \\
\hline CM57 & Equino & Passarela & & & & & 512 & R. bellii \\
\hline CM60 & Equino & Passarela & & & & & 256 & R. bellii \\
\hline CM64 & Equino & Passarela & & & & & 256 & R. bellii \\
\hline THE202 & Equino & H. Nazaré & 128 & & & & & R. amblyommii \\
\hline THE204 & Equino & H. Nazaré & 64 & 64 & 64 & 2048 & & R. riphicephali \\
\hline THE220 & Equino & H. Nazaré & 512 & 64 & 64 & 2048 & & R. riphicephali \\
\hline BEN258 & Equino & P. alegre & & & & 256 & & R. riphicephali \\
\hline VL159 & Equino & Angical & 256 & & 64 & & & R. amblyommii \\
\hline VL167 & Equino & Angical & 256 & & 64 & 64 & & R. amblyommii \\
\hline VL171 & Equino & Angical & 64 & & & 256 & & R. riphicephali \\
\hline VL175 & Equino & B. do curral & 256 & & 64 & 64 & & R. amblyommii \\
\hline VL180 & Equino & B. do curral & 256 & & & & & R. amblyommii \\
\hline VL187 & Equino & Campos & 256 & & & & & R. amblyommii \\
\hline CTL251 & Equino & C. do saco & 256 & & & & & R. bellii \\
\hline
\end{tabular}

Legenda: - R.A- R. amblyommii, R.P- R. parkeri, R.R- R. rickettsii, R.RPH- R. Rhipicephali, R.B- R. bellii, PAH- prováveis antígenos homólogos 
Com relação aos fatores de riscos analisados, cavalos estabulados e confinados em baias, apresentaram menor frequência de positividade para qualquer das rickettsia avaliadas $(p<0,001)$. Porém não houve associação entre os equinos confinados em piquetes e os que tinham acesso a mata $(p=0,02)$. Este fato representa a importância da exposição do animal ao vetor, animais com acesso a mata ou a piquetes, estariam sujeitos a uma maior infestação por carrapatos. Aqueles que adentram as matas também ficam expostos a uma maior variedade de ácaros uma vez que estas áreas são habitat de uma ampla ama de outros hospedeiros, vertebrados e carrapatos, que também podem ser vetores de Rickettisia.

O gráfico 6 relaciona os valores de soropositividade para rickettsias nos equinos por local de estudo. O Haras Santo Antônio, na microrregião de Campo Maior, foi a única localidade que demonstrou $100 \%$ de animais soronegativos. Apesar de carrapatos terem sido obtidos desses animais estes equinos permaneciam em baias individuais a maior parte do tempo.

Gráfico 6 - Número de equídeos positivos a anticorpos contra $R$. rickettsii pela RIFI por localidade amostrada

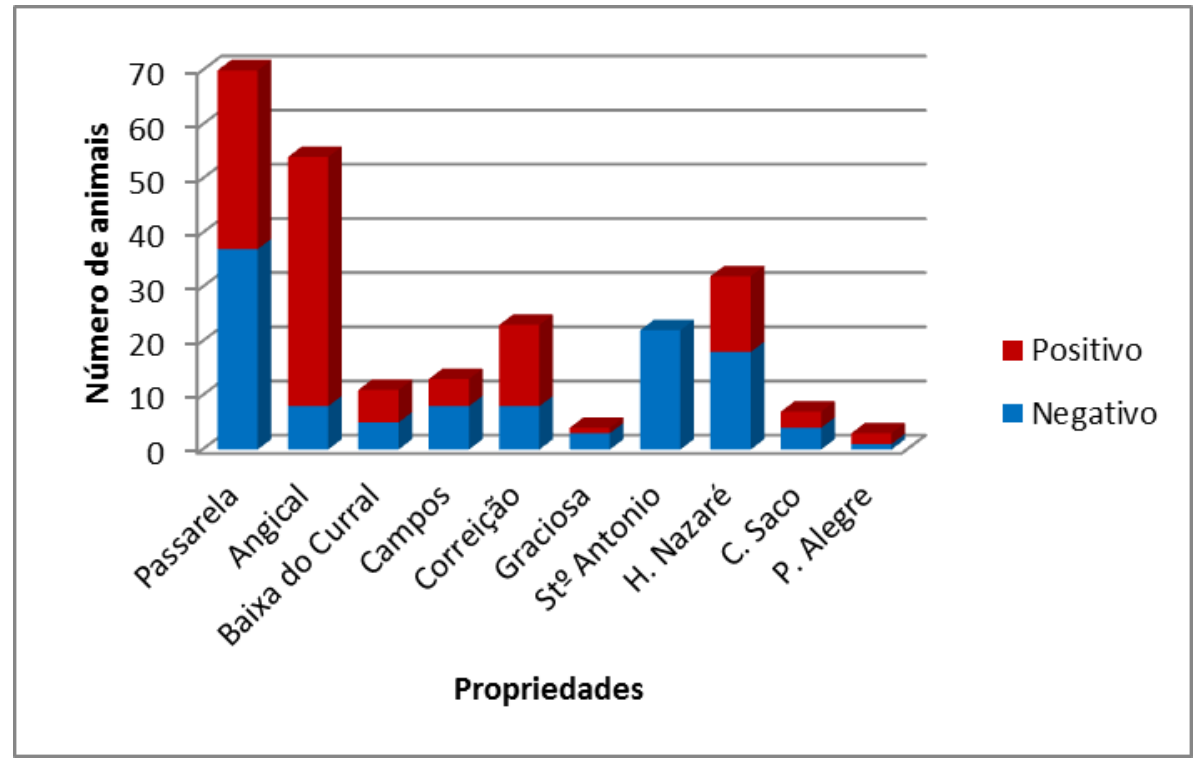

Em relação aos asininos da microrregião de Campo Maior, a frequência de positividade para $R$. bellii foi mais alta nos que estavam confinados em piquetes com vegetação nativa, quando comparados com aqueles que tinham acesso a mata 
$(p<0,001)$. Vale ressaltar que somente $D$. nitens foram encontrados parasitando os asininos desse estudo e que esse carrapato ainda não foi identificado como vetor de Rickettsia. Entretanto como somente duas visitas foram realizadas na mesma época em diferentes anos, maiores estudos devem ser feitos para conhecer-se melhor as espécies de carrapatos que enfestam estes animais. 


\section{CONCLUSÃO}

Conclui-se que "Candidatus Rickettsia andeanae" cepa Piauí e ou $R$. amblyommii, seria juntamente com $R$. bellii, os prováveis agentes circulantes na região centro-norte do estado do Piauí.

Dermacentor nitens, Amblyomma cajennense e Amblyomma parvum são espécies de carrapatos que infestam equídeos na mesorregião centro-norte do Piauí.

"Candidatus Rickettsia andeanae" cepa Piauí foi detectada através de PCR em carrapatos A. parvum. Sendo este o primeiro relato dessa bactéria no Brasil.

Animais com acesso à mata ou mantidos em piquetes apresentou associação com a ocorrência de anticorpos anti-Rickettsia spp em equinos. 


\section{REFERENCIAS}

ALMEIDA, D. N.; FAVACHO, A. R.; ROZENTAL, T.; BARCAUIB, H.; GUTERRES, A.; GOMES, R.; LEVIS, S.; COELHO, J.; CHEBABO, A.; COSTA, L. C.; ANDREA, S.; BARROSO, P. F.; LEMOS, E. R. S. Fatal spotted fever group rickettsiosis due to Rickettsia conorii . conorii mimicking a hemorrhagic viral fever in a South African traveler in Brazil. Ticks and Tickborne Diseases, v. 1, p. 149-150, 2010.

ANTÓN, E.; FONT, B.; MUÑOZ, T.; SANFELIU, I.; SEGURA, F. Clinical and laboratory characteristics of 144 patients with mediterranean spotted fever. European Journal of Clinical Microbiology \& Infectious Diseases, v. 22, p.126128, 2003.

APPERSON, C. S.; ENGBER, B.; NICHOLSON, W. L.; MEAD, D. G.; ENGEL, J.; YABSLEY, M. J.; DAIL, K.; JOHNSON, J.; WATSON, D. W. Tickborne diseases in North Carolina: is "Rickettsia amblyommii" a possible cause of rickettsiosis reported as Rocky Mountain spotted fever?. Vector Borne and Zoonotic Diseases, v. 8, p. 597-606, 2008.

ARAGÃO, H. B. (1936) Ixodidas brasileiros e de alguns paizes limitrophes. Memórias Instituto Oswaldo Cruz, v. 31, n. 4, p. 759-841, 1936.

AVILA-PIRES, F. D. Zoonoses: hospedeiro e reservatório. Caderno de Saúde Pública, v. 5, n. 1, 1989.

BACELLAR, F. C. Rickettsias isoladas e Portugal- contribuição para identificação e classificação das estirpes. 1996. 80-p Tese (Doutorado em Biologia) - Universidade de Ėvora, Évora, 1996.

BARROS-BATTESTI, D. M.; ARZUA, M.; BECHARA, H. G. Carrapatos de importância medico-veterinária da região neotropical: um guia ilustrado para identificação de espécies. 1. ed. São Paulo/BR: Vox/ICTTD-3/Butantã, 2006, 223p.

BATISTA, F. G.; SILVA, D. M.; GREEN, K. T.; TEZZA, L. B. L.; VASCONCELOS, S. P.; CARVALHO, S. G. S.; SILVEIRA, L.; JMORAES-FILHO, J.; LABRUNA, M. B.; FORTES, F. S.;MOLENTO, M. B. Serological survey of Rickettsia sp. in horses and dogs in an non-endemic area in Brazil. Revista Brasileira de Parasitologia Veterinária, v. 19, n. 4, p. 205-209, 2010.

BERMÚDEZ, S. E.; EREMEEVA, M. E.; KARPATHY, S. E.; SAMUDIO, F.; ZAMBRANO, M. L.; ZALDIVAR, Y.; MOTTA, J. A.; DASCH, G. A. Detection and 
identification of rickettsial agents in ticks from domestic mammals in eastern Panama. Journal of Medicine Entomology, v. 46, n. 4, p. 856-861, 2009.

BERRADA, Z. L.; GOETHERT, H. K.; CUNNINGHAM, J.; TELFORD, S. R. Rickettsia rickettsii (Rickettsiales: Rickettsiaceae) in Amblyomma americanum (Acari: Ixodidae) from Kansas. Journal of Medicine and Entomology, v. 48, n. 2, p. 461-467, 2011.

BILLETER, S. A.; BLANTON, H. L.; LITTLE, S. E.; LEVY, M. G.; BREITSCHWERDT, E. D. Detection of "Rickettsia amblyommil" in Association with a Tick Bite Rash. Vector-borne and zoonotic diseases, v. 7, n. 4, p. 607-610, 2007.

BILLINGS, A. N.; YU, X .J.; TEEL, P. D.; WALKER, D. H. Detection of a spotted fever group Rickettsia in Amblyomma cajennense (Acari: Ixodidae) in South Texas. Journal of Medical Entomology, n.35, p.474-478, 1998.

BLAIR, P. J.; JIANG, J.; SCHOELER, G. B.; MORON, C.; ANAYA, E.; CESPEDES, M.; CRUZ, C.; FELICES, V.; GUEVARA, C.; MENDOZA, L.; VILLASECA, P.; SUMMER, J. W.; RICHARDS, A. L.; OLSONM J. G. Characterization of spotted fever group rickettsiae in flea and tick specimens from northern Peru. Journal of Clinical Microbiology, v. 42, p. 4961-4970, 2004.

BORGES, L. M. F.; LEITE, R. C. Fauna ixodológica do pavilhão auricular de eqüinos de munic'ipios de Minas Gerais e da Bahia. Arquivos Brasileiros de Medicina Veterinária e Zootecnia, v. 50, p.87-89, 1998.

BURGDORFER, W. The hemolymph test $A$ technique for detection of rickertsiae in ticks.. American Journal of Tropical Medicine and Hygiene, v.19, n. 6, p.1010$1014,1970$.

BURGDORFER, W.; SEXTON, D. J.; GERLOFF, R. K.; ANACKER, R. L.; PHILIP, R. N.; THOMAS, L. A. Rhipicephalus sanguineus: vector of a new spotted fever group rickettsia in the United States. Infection and Immunity, v. 12, p. 205-210, 1975.

BRASIL. Ministério da Saúde. Secretaria de Vigilância em Saúde Guia de vigilância epidemiológica. Ministério da Saúde. 6. ed. Brasília: Ministério da Saúde, 2005. $816 p$.

BRASIL. Ministério da Saúde. Febre Maculosa: descrição da doença. Disponível em: 
http://portal.saude.gov.br/portal/saude/profissional/visualizar texto.cfm?idtxt=31458. Acesso em: maio de 2012.

CAMPOS PEREIRA, M.; SZABÓ, M. P. J.; BECHARA, G. H.; MATUSHIMA, E. R.; DUARTE, J. M. B.; RECHAV, Y.; FIELDEN, L.; KEIRANS, J. E. Ticks (Acari: Ixodidae) Associated with Wild Animals in the Pantanal Region of Brazil. Journal of Medical Entomology, v. 37, n. 6, p. 979-983, 2000.

CARDOSO, L. D. Detecção e caracterização de Rickettsia spp. circulante em foco inativo de Peri-Urbano do município de Caratinga - MG. 2004. 100f. Dissertação. Universidade Federal de Ouro Preto Ouro Preto, Ouro preto, 2004.

CARDOSO, L. D.; FREITAS, R. N.; MAFRA, C. L.; NEVES, C. V. B.; FIGUEIRA, F. C. B.; LABRUNA, M. B.; GENNARI, S. M.; WALKER, D. H.; GALVAO, M. A. M. Caracterização de Rickettsia spp. Circulante em Foco Silencioso de Febre Maculosa Brasileira no município de Caratinga, Minas Gerais, Brasil. Caderno de Saúde Pública, v. 22, n. 3, p. 495-501, 2006.

CASTAGNOLLI, K. C.; FIGUEIREDO, L. B.; SANTANA, D. A.; CASTRO, M. B.; ROMANO, M. A.; SZABÓ, M. P. J. Acquired resistance of horses to Amblyomma cajennense (Fabricius, 1787) ticks. Veterinary Parasitology, v. 117, p. 271-283, 2003.

CDC. Centers for Disease Control and Prevention. Diagnosis and Management of Tickborne Rickettsial Diseases: Rocky Mountain Spotted Fever, Ehrlichioses, and Anaplasmosis - United States; a practical guide for physicians and other health-care and public health professionals. Morbidity and Mortality Weekly Report. CDC: Atlanta, GA. v. 55, n. RR-4, p. 36, 2006..

CHILDS, J. E.; PADDOCK, C. D. The ascendancy of Amblyomma americanum as a vector of pathogens affecting humans in the United States. Annual Review of Entomology, v. 48, p. 307-337, 2003.

CHUNG, M. H.; LEE, S. H.; KIM, M. J.; LEE, J. H.; KIM, E. S.; LEE, J. S.; KIM, M. K.; PARK, M. Y.; KANG, J. S. Japanese Spotted Fever, South Korea. Emerging Infectious Diseases, v. 12, n. 7, p.1122-1124, 2006.

DANTAS-TORRES F. Rocky Mountain spotted fever. The Lancet Infectious Disease, v. 7, n. 11, p. 724-732, 2007. 
DANTAS-TORRES, F.; ONOFRIO, V. C.; BARROS-BATTESTI, D. M. The ticks (Acari: Ixodida: Argasidae, Ixodidae) of Brazil. Systematic e Applied Acarology, v. 14, p. 30-49. 2009.

DASCH, G. A.; KELLY, D. J.; RICHARDS, A. L.; SANCHEZ, J. L.; RIVES, C. C. Western blotting analysis of sera from military personnel exhibiting serological reactivity to spotted fever group rickettsiae. American Journal of Tropical Medicine and Hygiene, v. 49, 1993.

DEL FIOL, F. S.; JUNQUEIRA, F. M.; ROCHA, M. C. P.; TOLEDO, M. I.; FILHO, S. B. A febre maculosa no Brasil. Revista Panamericana de Salud Publica, v. 27, n. 6, p. 461-466, 2011.

DIAS, E.; MARTINS, A. V. Spotted fever in Brazil. The American Journal of Tropical Medicine and Hygiene, v. 19, p. 103-108, 1939.

DÍAZ, I. A. C. Rickettsiosis por Rickettsia conorii (fiebre botonosa del Mediterráneo o fiebre de Marsella), Estado actual en Uruguay. Revista Medica del Uruguay, v. 17, n. 2, p.119- 124, 2001.

DURDEN, L. A.; CUNNINGHAM, M. W.; MCBRIDE, R.; FERREE, B. Ectoparasites of freeranging pumas and jaguars in the Paraguayan Chaco. Veterinary Parasitology, v.15, p.189-93, 2006.

DUMLER, J. S.; BARBET, A. F.; BEKKER, C. P. J.; DASCH, G. A.; PALMER, G. H.; RAY, S. C.; RIKIHISA, Y.; RURANGIRWA, F. R. Reorganization of genera in the families Rickettsiaceae and Anaplasmataceae in the order Rickettsiales: unification of some species of Ehrlichia with Anaplasma, Cowdria with Ehrlichia and Ehrlichia with Neorickettsia, description of six new species combinations and designation of Ehrlichia equi and 'HGE agent' as subjective synonyms of Ehrlichia phagocytophila. Internal Journal of Systematic and Evolutionary Microbiology, v.51, n. 6, p.2145-2165, 2001.

ESTRIPEAUT D; ARAMBURU G. M; SAEZ-LLORENS X; THOMPSON H. A; A. DASH A. G; PADDOCK D. C; ZAKI S.; E. EREMEEVA E.M. Rocky Mountain Spotted Fever, Panamá. Emerging Infectious Diseases, v. 13, n. 11, p. 1763-1765, 2007.

FALCE, H. C.; FLECHTMANN, C. H. W.; FERNANDES, B. F. Ixodidae (Acari) on horses, mules and asses in the state of Paraná Brazil. Revista Faculdade de 
Medicina Veterinária e Zootecnia da Univiversidade de São Paulo, v. 20, p. 103106, 1983.

FIORELLO, C. V.; ROBBINS, R. G.; MAFFED, L.; WADE, S. E.; Parasites of freeranging small canids and felids in the Bolivian Chaco. Journal of Zoo and wildlife Medicine, v. 32, p. 130-134, 2006.

FOURNIER, P. E.; GOURIET, F.; BROUQUI, P.; LUCHT, F.; RAOULT, D. Lymphangitis-Associated Rickettsiosis, a New Rickettsiosis Caused by Rickettsia sibirica mongolotimonae: Seven New Cases and Review of the Literature. Clinical Infectious Diseases, v. 40, p.1435-1444, 2005.

FOURNIER, P. E.; GRUNNENBERGER, F.; JAULHAC, B.; GASTINGER, G.;RAOUL, D. Evidence of Rickettsia helvetica infection in humans. Eastern, France. Emerging Infection Diseases, v.6, n.4, p. 389-392, 2000.

GALVÃO, M. A. M.; SILVA, L. J.; NASCIMENTO, E. M. M.; CALIC, S. B.; SOUSA, R.; BACELLAR, F. Riquetsioses no Brasil e Portugal: ocorrência, distribuição e diagnóstico. Revista de Saúde Pública, v. 39, n. 5, p. 850-856, 2005.

GARRITY, G. M.; BELL, J. A.; LILBURN, T. G. Bergey's Manual of systematic of bacteriology. 2. Ed. Baltimore: Willians \& Wilkins, 2004.

GEHRKE, F. S. Detecção e caracterização molecular de riquétsias em humanos, potenciais vetores e animais domésticos da região sudeste do Brasil. 2010. Tese. Instituto de Ciências Biomédicas, Universidade de São Paulo, São Paulo, 2010.

GILOT, B.; LAFORGE, M. L.; PICHOT, J.; RAOULT, D. Relationships Between the Rhipicephalus sanguineus Complex Ecology and Mediterranean Spotted Fever Epidemiology in France. European Journal of Epidemiology, v.6, n.4, p. 357-362, 1990.

GIMEMEZ, D.F. Staining rickettsiae in yolk-sac cultures. Biotechnic \& Histochemistry, v.39, n. 3, p.135-40, 1964.

GUEDES, E.; LEITE, R. C.; PRATA, M. C. A.; PACHECO, R. C.; WALKER, D. H.; LABRUNA, M. B. Detection of Rickettsia rickettsii in the tick Amblyomma cajennense in a new Brazilian spotted fever-endemic area in the state of Minas Gerais. Memórias do Instituto Oswaldo Cruz, v. 100, n. 8, p. 841-845, 2005. 
GUGLIELMONE, A. A.; BEATI, L.; BARROS-BATTESTI, D. M.; LABRUNA, M. B.; NAVA, S.; VENZAL, J. M.; MANGOLD, A. J.; SZABÓ, M. P. J.; MARTINS, J. R.; GONZÁLEZ-ACUÑA, D.; ESTRADA-PEÑA, A. Ticks (Ixodidae) on humans in South America. Experimental and Applied Acarology, v. 40, p. 83-100, 2006.

GUGLIELMONE, A. A.; ESTRADA-PEÑA, A.; KEIRANS, A. J.; ROBBINS, R. G. Ticks (Acari). Ixodida of the Neotropical zoogeographic region. Special Publication of the International Consortiumon. Ticks and Tick-borne Diseases. Atlanta, Houten, The Netherlands, 2003,173 p.

GUGLIELMONE, A. A.; HADANI, A. Amblyomma ticks found on cattle in the Northwest of Argentina. Annales de Parasitologie, v. 57, p. 91-97, 1982.

GUGLIELMONE, A. A.; MANGOLD, A. J.; AGUIRRE, D. H.; GAIDO, A. B. Ecological aspects of four species of ticks found on cattle in Salta, Northwest Argentina. Veterinary Parasitology, v. 35, p. 93-101, 1990.

GUGLIELMONE, A. A.; MANGOLD, A. J.; VINABAL, A. E. Ticks (Ixodidae) parasitizing humans in four provinces of north-western Argentina. Annals of Tropical Medicine and Parasitology, v. 85, p. 539-542, $1991 \mathrm{~b}$.

GUGLIELMONE, A. A.; NAVA, S. Rodents of the Subfamily Caviinae (Hystricognathi, Caviidae) as hosts for hard ticks (Acari: Ixodidae). Mastozoologia Tropical, v, 17, n. 2, p. 279-286, 2011.

GUGlielmone, A. A., ROBBINS, R. G., APANESKEVICH, D. A., PETNEY, T. N., ESTRADA-PEÑA, A., HORAK, I. G., SHAO, R.; BARKER, S. A. The Argasidae, Ixodidae and Nuttalliellidae (Acari: Ixodida) of the world: a list of valid species names. Zootaxa, v. 2528, p. $1-28,2010$.

HARDEN, V. A. "Rocky Mountain Spotted Fever Research and the Development of the Insect Vector Theory, 1900-1930." Bulletin of the History of Medicine, v. 59 n. 4, p. 449-466, 1985.

HERRERO, J.I.H.; BELTRÁN, R. R.; SANCHEZ, A.M.M.; GARCIA, E.J. Mediterranean Spotted Fever in Salamanca, Spain. Epidemiological Study in Patients and Serosurvey in Animals and Healthy Human Population. Acta Tropica, v. 46, p. 335-350, 1989. 
HIDALGO, M.; MIRANDA, J.; HEREDIA, D.; ZAMBRANO, P.; VESGA, J. F.; LIZARAZO, D.; MATTAR, S.; VALBUENA, G. Outbreak of Rocky Mountain spotted fever in Córdoba, Colômbia. Memórias do Instituto Oswaldo Cruz, v. 106, n. 1, p. 117-118, 2011.

HORTA, M. C.; LABRUNA, M. B.; PINTER, A.; LINARDI, P. M.; SCHUMAKER, T. T. Rickettsia infection in five areas of the state of São Paulo, Brazil. Memórias do Instituto Oswaldo Cruz, v. 102, p. 793-801, 2007.

HORTA, M. C.; CHIEBAO D. P.; SOUZA D. B.; FERREIRA F.; PINHEIRO S. R.; LABRUNA M. B.; SCHUMAKER T. T. S. Prevalence of Rickettsia felis in the fleas ctenocephalides felis felis and Ctenocephalides canis from two Indian villages in Sao Paulo Municipality, Brazil. Annals of the New York Academy of Sciences, v. 1078, p.361-363, 2006.

HORTA, M. C.; LABRUNA, M. B.; SANGIONI, L. A.; VIANNA, M. C.; GENNARI, S. M.; GALVÃO, M. A.; MAFRA, C. L.; VIDOTTO, O.; SCHUMAKER, T. T.; WALKER, D. H. Prevalence of antibodies to Spotted Fever Group Rickettsiae in humans and domestic animals in a Brazilian Spotted Fever-Endemic area in the State of São Paulo, Brazil: Serologic evidence for infection by Rickettsia rickettsii and another spotted fever group Rickettsia. The American Journal of Tropical Medicine and Hygiene, v, 71, p. 93-97, 2004.

HSU, Y. M.; LIN, C. C.; CHOMEL, B. B.; TSAI, K. H.; WU, W. J.; HUANG, C. G.; CHANG, C. C. Identification of Rickettsia felis in fleas but not ticks on stray cats and dogs and the evidence of Rickettsia rhipicephali only in adult stage of Rhipicephalus sanguineus and Rhipicephalus haemaphysaloides. Comparative Immunology, Microbiology \& Infectious Diseases, v. 34, n. 6, p. 513-518, 2011.

IBARRA, V.; PORTILLO, A.; PALOMAR, A. M.; SANZ, M. M.; METOLA, L.; BLANCO. J. R.; OTEO, J. A.; Septic shock in a patient infected with Rickettsia sibirica mongolitimonae, Spain. European Society of Clinical Microbiology and Infectious Diseases, 2012. DOI: 10.1111/j.1469-0691.2012.03887.x

JONES, E. K.; CLIFFORD, C. M.; KEIRANS, J. E.; KOHLS, G. M. The thicks of Venezuela with a the species of Amblyomma in the Western Hemisphere. Brigham Young University, p 1-40. 1972.

JONGEJAN, F.; UILENBERG, G. The global importance of ticks. Parasitology, v. 129, p. 3-14, 2004.

KARDATZKE, J. T.; NEIDHARDT, K.; DZUBAN, D. P.; SANCHEZ, J. L.; AZAD, A. F. Cluster of tick-borne infections at Fort Chaffee, Arkansas: rickettsiae and Borrelia 
burgdorferi in ixodid ticks. Jounal of Medicine Entomology, v. 29, p. 669-672, 1992.

LABRUNA, M. B. Carta acarológica. Revista Brasileira de Parasitologia Veterinária, v.13, p.199- 202, 2004.

LABRUNA, M. B. Ecology of Rickettsia in South America. Annals of the New York Academy of Science, v. 1166, p. 156-166, 2009.

LABRUNA, M. B.; CAMARGO, L. M.; CAMARGO, E. P.; WALKER, D. H. Detection of a spotted fever group Rickettsia in the tick Haemaphysalis juxtakochi in Rondonia, Brazil. Veterinary Parasitology, v. 127, p.169-174, 2005c.

LABRUNA, M. B.; CAMARGO, L. M.; TERRASSINI, F. A. Ticks (Acari: Ixodidae) from the state of Rondônia, Western Amazon, Brazil. Systematic and Applied

Acarology, v. 10, p. 17-32, 2005a.

LABRUNA, M. B.; HORTA, M. C.; AGUIAR, D. M.; CAVALCANTE, G. T.; PINTER, A.; GENNARI, S. M.; CAMARGO, L. M. Prevalence of Rickettsia infection in dogs from the urban and rural areas of Monte Negro Municipality, western Amazon, Brazil. Vector Borne and Zoonotic Disease, v. 7, p. 249-255, 2007c.

LABRUNA, M. B.; JORGE, R. S. P.; SANA, D. A. Ticks (Acari:Ixodidae) on wild carnivores. Experimental and Applied Acarology, v. 36, p. 149-163, 2005b.

LABRUNA, M. B.; KASAI, N.; FERREIRA, F.; FACCINI, J. L. H.; GENNARI, S. M. Seasonal dynamics of ticks (Acari: Ixodidae) on horses in the state of São Paulo, Brazil. Veterinary Parasitology, v. 105, n. 1, p. 65-77, 2002.

LABRUNA, M. B.; KERBER, C. E.; FERREIRA, F.; FACCINI, J. L.; DE WAAL, D. T.; GENNARI, S. M. Risk factors to tick infestations and their occurrence on horses in the state of São Paulo, Brazil. Veterinary Parasitology, v. 97, p.1-14, 2001.

LABRUNA, M. B.; MATTAR, S. V.; NAVA, S.; BERMUDEZ, S.; VENZAL, J. M.; DOLZ, G.; ABARCA, K.; ROMERO, L.; SOUSA, R.; OTEO, J.; ZAVALA-CASTRO, J. Rickettsioses in Latin America, Caribbean, Spain and Portugal. Revista de medicina veterinaria e zootecnia de Córdoba, v. 16, n. 2, p. 2435-2457, 2011. 
LABRUNA, M. B.; MCBRIDE, J. W.; BOUYER, D. H.; CAMARGO, L. M. A.; CAMARGO, E. P.; WALKER, D. H. Rickettsia bellii and Rickettsia amblyommii in Amblyomma ticks from the state of Rondônia, Western Amazon, Brazil. Journal of Medical Entomology, v. 41, p.1073-1081, 2004a.

LABRUNA, M. B.; MCBRIDE, J. W.; BOUYER, D. H.; CAMARGO, L. M.; WALKER, D. H. Molecular evidence for a spotted fever group Rickettsia species in the tick Amblyomma longirostre in Brazil. Journal of Medical Entomology, v.41, p. 533$537,2004 b$.

LABRUNA, M.B.; PACHECO, R. C.; NAVA, S.; BRANDAO, P. E.; RICHTZENHAIN, L. J.; GUGLIELMONE, A. A. Infection by Rickettsia bellii and Candidatus "Rickettsia amblyommii" in Amblyomma neumanni ticks from Argentina. Microbial Ecology, $v$. 54, p. 126-133, 2007b.

LABRUNA, M. B.; PACHECO, R. C.; RICHTZENHAIN, L. J.; SZABÓ, M. P. Isolation of Rickettsia rhipicephali and Rickettsia bellii from ticks Haemaphysalis juxtakochi in the state of Sao Paulo, Brazil. Applied and Environmental Microbiology, v. 73, p. 869-873, 2007a.

LABRUNA, M. B.; PAULA, C. D.; LIMA, T. F.; SANA, D. A. Ticks (Acari: Ixodidae) on wild animals from the Porto-Primavera Hydroelectric Power Station Area, Brazil.

Memórias do Instituto Oswaldo Cruz, v. 97, p. 1133-1136, 2002a

LABUDA, M.; NUTTALL, P. A. Tick-borne viruses. Parasitology, v. 129, p. 221-245, 2004.

LEMOS, E. R. S.; MACHADO, R. D.; COURA, J. R.; GUIMARAES, M. A. A. M.; CHAGAS, J. N. Epidemiological aspectos of the brazilian spotted fever: serological survey of dogs and horses in a endemic area in the state of São Paulo, Brazil.

Revista do instituto de medicina tropical de são Paulo, v. 38, n. 6, p.427-430, 1996.

MAHARA F. Japanese spotted fever: report of 31 cases and review of theliterature. Emerging Infectious Diseases, v. 3, n. 2, p.105- 111, 1997.

MARTINO, O.; ORDUNA, T.; LOURTAU, L.; SCAPELLATO, P.; CERNIGO, B.; SEIJO, A. Rickettsioses do grupo das febres maculosas em viajantes argentinos. Revista da Sociedade Brasileira de Medicina Tropical, v. 34, n. 6, p. 559-562, 2001. 
MARTINS, J. R.; MEDRI, I. M.; OLIVEIRA, C. M.; GUGLIELMONE, A. A. Ocorrência de carrapato em tamanduá-bandeira (Myrmecophaga tridactyla) e tamanduá mirim (Tamandua tetradactyla) na região do Pantanal Sul Mato-Grossense, Brasil. Ciência Rural, v. 34, p. 293-295, 2004.

MEDEIROS, A. P.; SOUZA, A. P.; MOURA, A. B.; LAVINA, M. S.; BELLATO, V.; SARTOR, A. A.; NIERI-BASTOS, F. A.; RICHTZENHAIN, L. J.; LABRUNA, M. B. Spotted fever group Rickettsia infecting ticks (Acari: Ixodidae) in the state of Santa Catarina, Brazil. Memórias do Institudo Oswaldo Cruz, v. 106, n. 8, p.926-930, 2011.

MORAES-FILHO, J. Pesquisa de anticorpos anti-Rickettsia rickettsii em eqüinos do Centro de Controle de Zoonoses do município de São Paulo (CCZ/SP). Brazilian Journal of Veterinary Research and Animal Science, v. 46, n. 2, p.85-91, 2009.

NAVA, S.; CAPARROS, J. A.; MANGOLD, A. T.; GUGLIELMONE, A. A. Ticks(Acari:Ixodidae) Infesting humanas in Northwestern Cordoba Province, Argentina. Medicina, Buenos Aires, v. 66, p.225-228, 2006a.

NAVA, S.; MANGOLD, A. T.; GUGLIELMONE, A. A. The natural hosts for larvae and nymphs of Amblyomma neomanni and Amblyomma parvum (Acari: Ixodidae).

Experimental and Applied Acarology, v. 40, p. 123-31, 2006b.

OGATA, H.; SCOLA, B. L.; AUDIC, S.; RENESTO, P.; BLANC, G.; ROBERT, C.; FOURNIER, P. E.; CLAVERIE, J. M.; RAOULT, D. Genome Sequence of Rickettsia bellii Illuminates the Role of Amoebae in Gene Exchanges between Intracellular Pathogens. PLoS genetics, v. 2, 2006.

doi:10.1371/journal.pgen.0020076

OGRZEWALSKA, M.; PACHECO, R. C.; UEZU, A.; RICHTZENHAIN, L. J.; FERREIRA, F.; LABRUNA, M. B. Rickettsial infection in Amblyomma nodosum ticks (Acari: Ixodidae) from Brazil. Annals of Tropical Medicine and Parasitology, v. 103, p. 413-425, 2009.

OLIVER, Jr. J. H. Biology And Systematics Of Ticks (Acari: Ixodida). Review of Ecology and Systematics, v. 20, p. 397-430, 1989.

ONOFRIO, V. C.; VENZAL, J. M.; PINTER, A.; SZABO, M. P. J. Carrapatos de Importância Médico-Veterinária da Região Neotropical, c.4, p. 29-35, c. 6, p. 5371. 2006. 
PACHECO, R. C.; HORTA, M. C.; MORAES-FILHO, J.; ATALIBA, A. C.; PINTER, A.; LABRUNA, M. B. Rickettsial Infection In Capybaras (Hydrochoerus Hydrochaeris) From São Paulo, Brazil: Serological Evidence For Infection By Rickettsia Bellii And Rickettsia Parkeri. Biomédica, Revista del Instituto nacional del Salud, v. 27, p. 364-371, 2007

PACHECO, R. C.; HORTA, M. C.; PINTER, A.; MORAES FILHO, J.; MARTINS, T. F.; NARDI, M. S.; SOUZA, S. S. A. L.; SOUZA, C. E.; SZABÓ, M. P. J.; RICHTZENHAIN, L. J.; LABRUNA, M B. Pesquisa de Rickettsia spp em carrapatos Amblyomma cajennense e Amblyomma dubitatum no Estado de São Paulo. Revista Sociedade Brasileira de Medicina Tropical, v. 42, p. 351-353, 2009.

PACHECO, R. C.; MORAES-FILHO, J.; NAVA, S.; BRANDAO, P. E.; RICHTZENHAIN, L. J.; LABRUNA, M. B. Detection of a novel spotted fever group rickettsia in Amblyomma parvum ticks (Acari: Ixodidae) from Argentina. Expermental and Applied Acarology, v. 43, p. 63-71, $2007 \mathrm{~b}$.

PACHECO, R. C.; MORAES - FILHO, J.; GUEDES, E.; I. SILVEIRA, I.; L. J. RICHTZENHAIN, L. J.; R. C. LEITE, R. C.; LABRUNA, M. B. Rickettsial infections of dogs, horses and ticks in Juiz de Fora, southeastern Brazil, and isolation of Rickettsia rickettsii from Rhipicephalus sanguineus ticks. Medical and Veterinary Entomology, v. 25, p. 148-155, 2011.

PADDOCK, C. D.; SUMNER, J.W.; COMER, J. A.; ZAKI, S. R.; GOLDSMITH, C. S.; GODDARD, J.; McLELLAN, S. L. F.; TAMMINGA, C. L.; OHL, C. A. Rickettsia parkeri: A Newly Recognized Cause of Spotted Fever Rickettsiosis in the United States. Clinical Infectious Diseases, v.38, p.805-811, 2004.

PARIZI, F. L.; MASUDA, A.; JUNIOR, I. S. V. Modulation of the host immune system by ticks. Acta Scientiae Veterinariae, v. 35, p. 285-294, 2007.

PAROLA, P.; MATSUMOTO, K.; SOCOLOVSCHI, C.; PARZY, D.; RAOULT, D. A tick-borne rickettsia of the spotted-fever group, similar to Rickettsia amblyommii, in French Guyana. Annals of Tropical Medicine and Parasitology, v. 101, n. 2, p. 185-188, 2007.

PAROLA, P.; PADDOCK, C. D.; RAOULT, D. Tick Borne Rickettsioses around the world: Emerging Diseases Challenging Old Concepts. Clinical Microbiology Reviews, v. 8, n. 4, p. 719-756, 2005. 
PAROLA, P.; RAOULT, D. Ticks and tickborne bacterial diseases in humans: an emerging infectious threat. Clinical Infectious Diseases Chicago Journals, v. 33, p.897-928, 2001.

PEEL, M. C.; FINLAYSON, B. L.; MCMAHON, T. A. Updated world map of the Köppen-Geiger climate classification. Hydrology and Earth System Sciences, v. 11, p. 1633-1644, 2007.

PEREIRA, M. C.; SZABÓ, M. P. J.; BECHARA, G. H.; MATUSHIMA, E. R.; BARBANTE, M. J. D.; RECHAV, Y.; FIELDEN, L. Ticks (Acari: Ixodidae) Associated with Wild Animals in the Pantanal Region of Brazil. Journal of Medical Entomology, v. 37, p. 979-983, 2000.

PETERKOVÁ, K.; VANCOVÁ, I.; HAJNICKÁ, V.; SLOVÁK, M. Immunomodulatory arsenal of nymphal ticks. Medical and Veterinary Entomology, v. 22, p. 167-171, 2008.

PHILIP, R. N.; CASPER, E. A.; ANACKER, R. L.; CORY, J.; HAYES, S. F.; BURGDORFER, W.; YUNKER, C. E. "Rickettsia bellii" sp. nov.: a tick borne Rickettsia, widely distributed in the United States, that is distinct from the spotted fever and typhus biogroups. Internation Journal of Systematic and Evolutionary Microbiology, v. 33, p.94-106, 1983.

PINTER, A.; HORTA, M. C.; PACHECO, R. C.; MORAES-FILHO, J.; LABRUNA, M. $B$. Serosurvey of Rickettsia spp in dogs and humans from an endemic area for Brazilian spotted Fever in the state of São Paulo, Brazil. Cadernos de Saúde Pública, v. 24, n. 2, p. 247-252, 2008.

PINTER, A.; LABRUNA, M. B. Isolation of Rickettsia rickettsii and Rickettsia bellii incell culture from the tick Amblyomma aureolatum in Brazil. Annals of the New York Academy of Science, v. 1078, p. 523-529. 2006.

RANDOLPH, S. E.; CRAINE, N. G. General Framework for Comparative Quantitative Studies on Transmission of Tick-Borne Dieseases Using Lyme Borreliosis in Europe as an Example. Entomological Society of America, v. 32, p. 765 - 777, 1995.

RAOULT D.; ROUX, V. Rickettsioses as paradigms of new or emerging infectious diseases. Clinical Microbiology Reviews, v. 10, n. 4, p. 694-719, 1997.

REGNERY, R. L; SPRUILL, C.L; PLIKAYTIS, B. D. Genotypic identification of rickettsiae and estimation of intraspecies sequence divergence for portions of two rickettsial genes. Journal of Bacteriology, v.173, p.1576-1589, 1991. 
ROBY, T. O.; ANTHONY, D. W. Transmission of equine piroplasmosis by Dermacentor nitens Neumann. Journal of American Veterinary Medicne Association, v. 142, p. 768-769, 1963.

ROJAS, R.; MARINI, M. A.; COUTINHO, M. T. Z. Wild birds as hosts of Amblyomma cajennense (Fabricius, 1787) (Acari: Ixodidae). Memorias do Instituto Oswaldo Cruz, v. 94, p. 315-322, 1999.

ROMER, Y.; SEIJO, A.C.; CRUDO, F.; NICHOLSON, W. L.; STOKES, A. V.; LASH, R. R.; PADDOCK, C. D. Rickettisia parkeri Rickettsiosis , Argentina. Emerging Infectious Diseases, v. 17, n. 7, 2011.

ROUX, V.; RAOULT, D. Phylogenic analysis of members of the genus Rickettsia using the gene encoding the outer-membranse protein rOmpB (OmpB). International Journal of Systematic and Evolutionary microbiology, v. 50, p. 1449-1455, 2000.

RUMASZKAN, G.; JUNQUEIRA, R. R.. O cavalo. Itatiaia: Belo Horizonte, Brasil, 1980.11p.

SABATINI, G. S.; PINTER, A.; NIERI-BASTOS, F. A.; MARCILI, A.; LABRUNA, M. $B$... Survey of ticks(Acari: Ixodidae) and their rickettsia in an Atlantic rain forest reserve in the State of São Paulo. Brazilian Journal of Medical Entomology, v. 47, p. 913-916. 2010.

SANCHEZ, J. L.; CANDLER, W. H.; FISHBEIN, D. B.; GREENE, C. R.; COTÉ, T. R.; KELLY, D. J.; DRIGGERS, D. P.; JOHNSON, B. J. A cluster of tick-borne infections: association with military training and asymptomatic infections due to Rickettsia rickettsia. Transactions of Royal Society of Tropical Medicine and Hygiene, v.86, p. 321-325, 1992.

SANGIONI, L. A.; HORTA, M. C.; VIANNA, M. C. B.; GENNARI, S. M.; SOARES, R. M.; GALVÃO, M. A. M.; SCHUMAKER, T. T. S.; FERREIRA, F.; VIDOTTO, O.; LABRUNA, M. B. Rickettsial infection in animals and brazilian spotted fever endemicity. Emerging Infectious Diseases, v. 11, n. 2, p. 265-270, 2005.

SARAIVA, D. G.; FOURNIER, G. F. S. R.; MARTINS, T. F.; LEAL, K. P. G.; VIEIRA, F. N.; CAMARA, E. M. V. C.; COSTA, C. G.; ONOFRIO, V. C.; BARROS-BATTESTI, D. M.; GUGLIELMONE, A. A.; LABRUNA, M. B. Ticks (Acari: Ixodidae) associated 
with small terrestrial mammals in the state of Minas Gerais, southeastern Brazil. Experimental applied and acarology, 2012.

SHAW, S. E; BIRTLES, R. J; DAY, M. J. Arthropod-transmitted infectious diseases of cats. Journal of Feline Medice \& Surgery, v. 3, p.193-209, 2001.

SILVEIRA, I. Investigação da infecção pela bactéria Rickettsia parkeri em carrapatos Amblyomma triste no Estado de São Paulo. 2006. Dissertação (Mestrado em Epidemiologia Experimental e Aplicada às Zoonoses). Faculdade de Medicina Veterinária e Zootecnia, Universidade de São Paulo, São Paulo, 2006.

SOUSA, R.; NÓBREGA, S. D.; BACELLAR, F.; TORGAL, J. Sobre a realidade da febre escaro-nodular em Portugal. Acta Médica Portuguesa, v.16, p. 429-436, 2003.

SPOLIDORIO, M. G.; LABRUNA, M. B.; MANTOVANI, E.; BRANDAO, P. E.; RICHTZENHAIN, L. J.; YOSHINARI, N. H. Novel spotted Fever group rickettsiosis, Brazil. Emerging Infectious Diseases, v. 16, p. 521-523. 2010.

STOTHARD, D. R.; CLARK, J. B.; FUERST, P. A. Ancestral Divergence of Rickettsia beZlii from the Spotted Fever and Typhus Groups of Rickettsia and Antiquity of the Genus Rickettsia. International journal of systematic bacteriology, v. 44, n. 4, p. 798-804, 1994.

STROMDAHL, E. Y.; VINCE, M. A.; BILLINGSLEY, P. M.; DOBBS, N. A.; WILLIAMSON, P. C. Rickettsia amblyommii infecting Amblyomma americanum larvae. Vector Borne and Zoonotic Diseases, v.8, p. 15-24, 2008.

SZABÓ, M. P. J.; PEREIRA, L. F.; CASTRO, M.B.; GARCIA, M. V.; SANCHES, G. S.; LABRUNA, M. B. Biology and life cycle of Amblyomma incisum (Acari:Ixodidae). Experimental and Applied Acarology, v. 48, p. 263-271, 2009a.

SZABÓ, M. P.; OLEGÁRIO, M. M.; SANTOS, A. L.. Tick fauna from two locations in the Brazilian savannah. Experimental and Applied Acarology, v. 43, p. 73-84, 2007.

TAMEKUNI, K.; TOLEDO, R. S.; FILHO, M. F. S.; HAYDU, V. B. H.; PACHECO, R. C.; CAVICCHIOLI, J. H.; LABRUNA, M. B.; DUMLER, J. S.; VIDOTTO, O.

Serosurvey of antibodies against spotted fever group Rickettsia spp. in horse farms in Northern Paraná, Brazil. Revista Brasileira de Parasitologia Veterinaria, v. 19, n. 4, p. 259-261, 2010. 
TAMURA, A. OHASHI, N.; URAKAMI, H.; MIYAMURA, S. Classification of Rickettsia tsutsugamushi in a new Genus, Orientia gen. nov., as Orientia tsutsugamushi comb. nov. International Journal of systematic Bacteriology, v.45, n.3, p.589-591, 1995.

TOMASSONE, L.; NUÑEZ, P.; CEBALLOS, L. A.; GURTLER, R. E.; KITRON, U.; FARBER, M. Detection of Candidatus Rickettsia sp. strain Argentina" and Rickettsia bellii in Amblyomma ticks (Acari: Ixodidae) from Northern Argentina. Experimental and Applied Acarology, v. 52, p. 93-100, 2010.

TORRES, A. D.; JARDIM, W. R. Criação do cavalo e de outros eqüinos. São Paulo: Nobel; 1985. 282 p.

TITUS, R. G.; BISHOP, J. V,; MEIJA, J. S. The immunomodulatory factors of arthropod saliva and the potential for these factors to serve as vaccine targets to prevent pathogen transmission. Parasite Immunology, v. 28, p. 131-141, 2006.

USLAN, D. Z.; SIA, I. G. African Tick-Bite Fever. Mayo Clinic Proceedings. Mayo Clinic Proceedings, v. 79, n. 8, p.1007, 2004.

VENZAL, J. M.; PORTILLO, A.; ESTRADA-PEÑA, A.; CASTRO, O.; CABRERA, P. A.; OTEO, J. A. Rickettsia parkeri in Amblyomma triste from Uruguay. Emerging Infectious Diseases Journal Homepage, v.10, p.1493- 1495, 2004.

VIANNA, M. C. B.; HORTA, M. C.; SAGIONI, L. A.; CORTEZ, A.; SOARES, R. M.; MAFRA, C. L.; GALVAO M. A. M.; LABRUNA, M. B.; GENNARI, S. M. Rickettsiose do grupo da febre maculosa na Vila de Capoeirão, Itabira, Minas Gerais, Brasil. Revista do Instituto de Medicina Tropical de São Paulo, v. 50, n. 5, p. 297-301, 2008.

YU, X. J.; WALKER, D. H. The order Rickettsiales. In: DWORKIN, M. (Ed.). The Prokaryotes: an evolving electronic resource for the microbiology community. 3 ed. New York: Springer, Velag, 2003. 5237 p.

WALKER, D. H.; FISHBEIN, D. B. Epidemiology of Rickettsial diseases. European Journal of Epidemiology, v. 7, p. 237-245, 1991.

WEISS, E.; MOULDER, J. W. The Rickettsias and Chlamydias. In: KREIG N.R. HOLT J.G. Manual of Systematic Bacteriology. . Baltmore: Bergey's, 1984 v.1. 
WOOLLEY, T. A. Acarology. Mites and human welfare. Fort Collins: Library of Congress, 1988. 484 p.

ZHU, Y.; FOURNIER, P. E.; EREMEEVA, M.; RAOULT, D. Proposal to create subspecies of Rickettsia conorii based on multi-locus sequence typing and an emended description of Rickettsia conorii. BMC Microbiology, v. 5, p. 5- 11, 2005. 